NBER WORKING PAPER SERIES

\title{
DO WORKERS GAIN BY SHARING? EMPLOYEE OUTCOMES UNDER EMPLOYEE OWNERSHIP, PROFIT SHARING, AND BROAD-BASED STOCK OPTIONS
}

\author{
Douglas Kruse \\ Richard Freeman \\ Joseph Blasi \\ Working Paper 14233 \\ http://www.nber.org/papers/w14233
NATIONAL BUREAU OF ECONOMIC RESEARCH
1050 Massachusetts Avenue
Cambridge, MA 02138
August 2008

Presented at the Russell Sage/NBER conference in New York City, October 2006. We thank Michael Handel and other participants for valuable comments. An earlier version of this paper was presented at the Labor and Employment Relations Association conference, January 5-8, 2006, Boston, Massachusetts. This research is supported by a grant from the Russell Sage Foundation and the Rockefeller Foundation. The National Opinion Research Center at the University of Chicago provided valuable assistance with the General Social Survey segment that forms the basis for some of the analysis. Refen Koh, Michelle Pinheiro, Rhokeun Park, and Patricia Berhau provided excellent assistance in survey scanning, entry, and verification. The views expressed herein are those of the author(s) and do not necessarily reflect the views of the National Bureau of Economic Research.

NBER working papers are circulated for discussion and comment purposes. They have not been peerreviewed or been subject to the review by the NBER Board of Directors that accompanies official NBER publications.

(C) 2008 by Douglas Kruse, Richard Freeman, and Joseph Blasi. All rights reserved. Short sections of text, not to exceed two paragraphs, may be quoted without explicit permission provided that full credit, including $\odot$ notice, is given to the source. 
Do Workers Gain by Sharing? Employee Outcomes under Employee Ownership, Profit Sharing, and Broad-based Stock Options

Douglas Kruse, Richard Freeman, and Joseph Blasi

NBER Working Paper No. 14233

August 2008

JEL No. J33,J54,L23

\title{
ABSTRACT
}

This paper examines how shared capitalism compensation systems - those that link employee pay to company performance - affect diverse employee outcomes. It uses two data sets: the national GSS survey that provides a broad representative view of the extent of the programs; and the NBER Shared Capitalism Project surveys of workers in 14 companies that use shared capitalism programs extensively. We find that greater involvement in the programs is generally linked to greater participation in decisions, higher quality supervision and treatment of employees, more training, higher pay and benefits, greater job security, and higher job satisfaction. We also find positive interactions of shared capitalism with high-performance policies in predicting participation in decisions and overall job satisfaction, and negative interactions of shared capitalism with close supervision in affecting almost all of the outcomes. Overall the results support the idea that workers can gain by sharing, but whether this happens is contingent on other workplace policies.

\author{
Douglas Kruse \\ School of Management and Labor Relations \\ Rutgers University \\ 94 Rockafeller Road \\ Piscataway, NJ 08854 \\ and NBER \\ dkruse@ rci.rutgers.edu \\ Richard Freeman \\ NBER \\ 1050 Massachusetts Avenue \\ Cambridge, MA 02138 \\ and NBER \\ freeman@nber.org
}

Joseph Blasi

Rutgers University

School of management and Labor Relations

Levin Building

New Brunswick, NJ 08544

and NBER

jrbru@hotmail.com 
Today, more employees than ever before have ownership stakes in their firms through ESOPs and firm-based stock ownership plans, receive stock options once limited to top executives, and are covered by profit-sharing plans. The media has publicized both the rewards and dangers of tying worker pay and wealth to company performance. The 1990's produced many stories of regular employees becoming millionaires by working in Silicon Valley firms with broad-based options that paid off handsomely. The early 2000's produced stories about Enron employees losing their retirement moneys in a 401(k) plan that was heavily concentrated in company stock. Apart from the extreme cases that get publicized, are these programs generally good or bad for workers?

This paper analyzes the relationship of shared capitalism programs to a range of employee outcomes: participation in decisions, supervision, training, company treatment of employees, pay, job security, and job satisfaction. It uses data from the 2002 and 2006 General Social Surveys (GSS), which covered 2226 persons in for-profit firms from a nationally representative sample, and data from an NBER-sponsored firm based survey of over 40,000 employees at 320 worksites in 14 companies for whom these programs are a key part of their compensation systems.

\section{WHAT WE EXPECT}

On the basis of incentive and organization theory and previous empirical work, we expect that linking employee pay to company performance will impact workers in several ways.

\section{Employee Participation in Decision-Making}

Shared capitalist compensation systems should be associated with greater freedom for workers to make decisions at their workplace. It is difficult to imagine a firm devolving decisions to workers without developing some pecuniary mechanism for motivating them to make decisions in the firm's interest, be it profit-sharing, gain-sharing, stock options or share ownership. Indeed, 
one common reason for firms to institute compensation systems relating employee pay to company performance is to induce workers to make decisions that improve firm performance. ${ }^{1}$

Two national surveys of workers have found the expected relation. For the U.S., Dube and Freeman (2001) found a positive relation between shared capitalist compensation systems and employee decision-making in Freeman and Rogers’ (1999) Workers Representation and Participation Survey, with strong results for profit-sharing but weak results for employee ownership. For the UK, Conyon and Freeman (2004) found a positive link between changes in variable pay and changes in decision-making in the Workplace Employment Relations Survey. However, firm-based studies of employee ownership find only a weak pattern between perceived or desired participation in decision-making and employee ownership. Half of the ten studies reviewed by Kruse and Blasi (1997) found participation levels higher with employee ownership while half found no difference in participation. None of the studies found a connection between participation in decisions and the size of one's ownership stake. Two of the studies that asked about desired participation found no difference between employee-owners and non-owners, while a third study found a decline in desired worker participation after an employee buyout, which the author attributes to wariness by employees about the commitment levels of new employees and trust in management (Long, 1981, 1982).

\section{Supervision, Training, and Treatment of Workers}

Any shared compensation system must overcome potential free rider problems. The larger the number of people who share in the rewards of the firm or group, the lower is the incentive for

\footnotetext{
${ }^{1}$ Over 60 studies indicate that profit sharing, employee ownership, and stock options are associated with better firm performance on average. However, there is a great dispersion around that average as some companies greatly outperform, and others under perform their non-sharing counterparts, for reasons that research has not yet pinned down. (Kruse and Blasi, 1997; Kruse, 2003; Blasi, Kruse, and Bernstein, 2003).
} 
the individual to work hard and the greater the reward to shirking. In our companion paper, we find that worker monitoring of the group is an important mode for overcoming the free rider problem (Freeman, Kruse, and Blasi 2008). Firms cannot force workers to self-monitor but they can provide supportive supervision, training, and a workplace climate that encourages group norms to sustain a self-monitoring equilibrium.

Few studies have examined the relation of shared capitalism programs to supervision, training, and workplace climate. Brown and Sessions (2003) report that employees in performance-related pay plans have more positive views about management-employee relations and how the workplace is run. Two studies have found that employee in profit-sharing plans are more likely to receive employer-provided training (Azfar and Danninger, 2001; Robinson and Zhang, 2005). Two studies have examined whether workplaces are safer under shared employee ownership. Rooney (1992) found fewer OSHA injuries in employee ownership companies with greater worker participation in decisions, but otherwise found mixed results for ownership without participation. Rhodes and Steers (1981) found that accidents were no lower in a plywood cooperative compared to a standard plywood company.

\section{Pay and Benefits}

There are two reasons for expecting shared capitalist compensation systems to be associated with higher pay and benefits.

First, shared capitalist systems could operate in part as a "gift exchange" between the worker and the firm, in which the higher pay increases worker effort, decreases turnover, and increases worker loyalty (Akerlof, 1982). By encouraging employee cooperation, shared capitalism programs could increase output, some of which would go to workers as their share of 
profits and some as higher base wages or benefits. The sharing system would be a key component of a mutual-gains or high-commitment system where both workers and the firms come out ahead (Handel and Levine, 2004: 5). Second, since shared capitalism increases risk to workers, compensating differential theory predicts that workers will want higher overall compensation. Whether this compensation takes the form of fixed pay and benefits or shows up in a larger share in profits and ownership is unclear. Again, what creates the potential for higher income to workers is the higher productivity generated by the system.

Despite some well-publicized examples of wage concessions when workers buy out their companies or accept large ownership stakes (which make up a very small percentage of the employee ownership landscape), workers in employee ownership plans tend to have comparable or higher wages or compensation than other workers. Blasi et al. (1996) found that public companies with broad-based employee ownership plans had 8\% higher average compensation levels than other comparable public companies, and compensation increased with the percentage of stock held by employees. Studies of pay and benefits in ESOP and non-ESOP firms in Massachusetts and Washington state also found that the levels of pay and other benefits were similar between these two types of firms, so that ESOPs appear to come on top of other worker pay and benefits (Kardas et al., 1998; Scharf and Mackin, 2000). With regard to other forms of ownership, Renaud et al. (2004) found that stock purchase plan participation was associated with subsequent pay increases for employees, and employer stock held in 401(k) plans appears to come largely on top of other pension assets (Kroumova, 2002). Seven studies from the U.S., Great Britain, and Germany find that profit-sharing firms also have generally higher average compensation than otherwise-comparable firms (Kruse, 1993: 113-114; Handel and Gittleman, 2004). 
Still, it is possible that the higher pay levels associated with shared capitalist compensation reflect higher unmeasured worker quality, and that workers in fact take a cut in compensation to link their pay to company performance. But the evidence runs against these possibilities. Kruse (1998) found that average base pay levels and other benefits increase as young workers join profit-sharing firms and decrease as they leave such firms, so worker selectivity cannot dominate the cross-sectional relation. Similarly, Azfar and Danninger (2001) found that employees in profit-sharing plans receive higher annual raises in base pay than employees in other firms, connected in part to the greater training noted earlier. Other studies find that neither wages nor total labor costs exclusive of the sharing component fall significantly in pre/post comparisons of firms that adopt profit sharing (Black et al., 2004, for wages; Cappelli and Neumark, 2004, for total labor costs). The implication is that trade-offs between base pay and shared capitalist compensation are minimal and that profit sharing may be used in conjunction with higher base pay levels as part of an efficiency wage strategy.

Another possibility is that the higher monetary compensation associated with shared capitalist systems may come at the cost of greater effort, stress, workplace danger, or other disamenities at work. Some analysts view the systems as a bit of a sham, designed to elicit greater worker effort and to shift risk to workers, without increasing the pay or quality of jobs. This is "'management by stress' ... which believes that [employee involvement] is simply a method of sweating the workforce and curbing worker power and influence" (Handel and Levine, 2004: 6).

Our data allows us to compare compensation for workers covered and not covered by the shared capitalist compensation and to compare compensation for workers by the intensity of their shared compensation arrangements. 


\section{Job security}

Traditional analysis of labor-run firms predicts that they have lower employment than in management-run firms, and respond perversely to demand shocks, lowering employment when output prices increase (reviewed in Bonin and Putterman, 1987). Most analyses show that employee ownership firms tend to have more stable employment than other firms, but do not respond perversely to demand shocks (Craig and Pencavel, 1992, 1993; Blair et al., 2000). Two studies report that employment grew faster in firms following the adoption of ESOPs, particularly if they have greater employee participation in decision-making (Quarrey and Rosen, 1993; Winther and Marens, 1997). In addition, public firms with substantial employee ownership are more likely than other comparable firms to survive over time (Blair et al., 2000; Park et al., 2004). French worker cooperatives also have high rates of survival (Estrin and Jones, 1992).

Profit sharing, in contrast, should create excess demand for employment and thus provide substantial job security (Weitzman, 1984). Nineteen studies have examined Weitzman's predictions that profit sharing should stabilize firm employment (Kruse, 1998: 109-113). A majority found that firms view profit sharing differently from fixed wages in making employment decisions. Of the twelve studies directly examining employment stability, six found greater employment stability under profit sharing; four showed greater stability in some but not all samples; while two have little or no support for the stabilizing effects of profit sharing.

\section{Job satisfaction}

If shared capitalism is associated with greater participation and decision-making at the workplace, better supervision, more training, more job security and higher total compensation, these modes of pay ought to raise job satisfaction. But the 12 existing studies on job satisfaction 
under employee ownership yield no clear generalization. ${ }^{2}$ Several studies show higher satisfaction; several show no relationship; and one study shows lower satisfaction among employee-owners where the union had lost a bitter strike the year before. ${ }^{3}$ Participation in decisions seems to be important: one longitudinal study found that satisfaction went up only among those who perceived increased participation in decisions after an employee buyout (Long, 1982). Our data provide the largest sample for assessing these inconclusive findings.

In sum, prior research on employee outcomes under shared capitalism has yielded generally positive results, though there is sufficient variability in some results to suggest that they depend on the context in which they are implemented. By addressing all of the employee outcomes with the GSS and the NBER data sets, and providing more robust measures of the employment context inside these firms, we should be better able to provide a more consistent generalization than the existing work.

\section{DATA AND ANALYSIS}

The NBER Shared Capitalism Research Project uses two data sets to analyze how shared capitalist arrangements affect workers. The first is the 2002 and 2006 General Social Surveys (GSS), on which we placed several questions on shared capitalism programs. The 2002 GSS has a representative sample of 1,145 employees, and the 2006 GSS has a sample of 1,081 employees, in for-profit companies. The second is a data set of employee surveys in 14 companies with one or more shared capitalism programs, which we conducted over the 2001-2006 period. We selected these companies to vary in company size, industry, and type of shared capitalism program. Even

\footnotetext{
${ }^{2}$ This is based on nine studies on job satisfaction reviewed in Kruse and Blasi (1997), plus Pendleton et al. (1998), Keef (1998), and Bakan et al. (2004). The studies were selected if they used systematic data collection from representative samples of employees, and used statistical techniques to rule out sampling error. Many used multivariate analysis to hold constant the effect of other factors on employee attitudes or behavior.
} 
so, our sample is non-representative, first because many firms refused our requests to run the survey; and second because two of the firms were bought out by others who refused to proceed with the planned survey. Each company in the sample agreed to have our research group administer a survey to all or a random sample of employees. The survey included core questions common across all companies, and some questions of special interest or relevance to that company. Six company surveys were conducted entirely by web, seven company surveys were done on paper, and one survey was done using both the web and paper surveys. The company response rates ranged from $11 \%$ to $80 \%$, with an average of $53 \%$ across the 14 companies. A total of 41,206 respondents provided usable surveys. Appendix A describes the variables used in this analysis. Companion papers that analyze the GSS and NBER datasets include Blasi, Kruse, and Markowitz (2008), Blasi et al. (2008), Buchele et al. (2008), Budd (2008), Carberry (2008), Freeman, Kruse, and Blasi (2008), Harden, Kruse, and Blasi (2008), and Kruse, Freeman, and Blasi (2008).

The overall prevalence of shared capitalist compensation is presented in Appendix Table A-1, with fuller presentation in our companion paper (Kruse, Blasi, and Park 2008). For our purposes here the most important result is that $45 \%$ of the for-profit private sector employees in the GSS sample report participating in some kind of shared capitalism program (36\% in profit sharing, $25 \%$ in gainsharing, $19 \%$ in employee ownership, and $11 \%$ in stock options), which gives us good variation for examining the relation of these programs to worker outcomes. The prevalence is of course higher in the NBER sample, since these firms were selected on the basis of having these programs.

\footnotetext{
${ }^{3}$ Reminders by management that the strike would hurt ESOP account values brought the response "We don't vote; we don't control the company; we don't care" (Kruse, 1984).
} 
As a first step in assessing the relation of shared capitalism to employee outcomes, we constructed a thermometer-style index of shared capitalism, which assigns points based on coverage by shared capitalism programs and the size of the financial stakes. This index is described in Appendix B. We also present results breaking out the different forms of shared capitalism types and intensities using the NBER data.

Turning to employee outcomes, we have organized responses to questions in eight areas: participation in decisions, company treatment of employees, supervision, training, pay and benefits, co-worker relations, job security, and job satisfaction. These outcomes are related to each other-e.g., training generally leads to higher pay; participation in decisions, training, job security, and supervision are likely to affect perceptions of how the company treats employees; and so on. We lack instruments to identify causality, so we do not try to tease out possible causal links among the outcomes. Rather, we first test for the reduced form relationship between shared capitalism and each of the individual outcomes conditional on demographic and job characteristics, and in some cases on other outcomes as well—e.g., since company training is likely to affect pay, we examine whether shared capitalism is related to pay both before and after controlling for training.

\section{EMPIRICAL RESULTS}

We first use the shared capitalist index to predict each of the outcomes (Table 1), and then probe the impact of different types and intensities of shared capitalist compensation (Tables B-1 to B-5). We estimate OLS regressions when outcomes are numeric and use ordered probits when the outcomes have three or four values with a natural ordering (e.g., "not at all true, not very true, somewhat true, and very true"). The regression predicting hours of training use a Tobit specification, to account for the censoring at zero. Most of the regressions using the NBER dataset 
include company fixed effects so that coefficients reflect within-company differences rather than cross-company differences that might be due to unmeasured differences among the companies. At the bottom of Tables B-1 to B-5, some ESOP coefficients are reported where company fixed effects are not used. Federal ERISA law imposes strict requirements on coverage so that most or all employees are covered by an ESOP within a firm; the small number of excluded employees are thus likely to differ in some particular way from other employees in the same firm. Because of this the ESOP effects are better determined by comparing otherwise-similar ESOP and non-ESOP workers across firms in the specifications without fixed effects.

Table 1 summarizes our empirical results in terms of the coefficients on the shared capitalism summated rating index variable for the seven outcomes under study. In most cases, we examine more than one outcome under the specified domain.

\section{Employee participation in decisions}

Almost all of the measures of participation in decision-making in Table 1 are positively and significantly related to the shared capitalism index. There are two exceptions in the NBER data -- the relationships with participation in company decisions and satisfaction with participation in the NBER data, but only after controlling for other outcomes (employee involvement team, training, and job security). This indicates that shared capitalism is strongly correlated with these policies, and the package of these policies may be the most important determinant (which we examine in Table 2).

When the shared capitalism policies are broken out in Appendix Table B-1, the most consistent result is that profit sharing intensity (measured using the most recent bonus as a percent of pay) is linked to greater participation in decisions and greater satisfaction with participation (cols. 1-5). The small negative coefficients on profit sharing eligibility (cols. 2, 3, and 5) indicate 
that very low profit sharing bonuses are associated with lower participation and satisfaction—an effect that is erased as the bonus size increases. In addition, while employee ownership is linked to greater participation in decisions (cols. 1-4) but satisfaction with participation is linked to employee-owned stock as a percent of pay (col. 5).

Examining the different types of employee ownership, the data show some significant associations but no strong patterns. 401(k) stock intensity is associated with greater involvement in job and department decisions (cols. 1-2), while involvement in company decisions is highest among those with any 401(k) employer stock or those who retain stock from exercised options (col. 3). These latter two groups are also more likely to be in EI teams (col. 4), while satisfaction with participation is highest among those holding open market stock or with large ESOP or 401(k) stakes (col. 5). As noted earlier, given the ERISA rules about coverage within a company, it is more sensible to make inferences about the effects of ESOPs by comparing workers between companies with and without ESOPs, which requires elimination of company fixed effects in the calculations. When this is done at the bottom of Table B-1, the estimates show that ESOP participants are more likely to be involved in job, department, and company decisions (cols. 1-3), but are much less likely to be satisfied with their participation (col. 5). This latter result, which is consistent with the within-company comparison, suggests that the simple membership in ESOPs in these companies may have raised the desire for participation more than they raised actual participation (or alternatively, that the additional participation itself raised desires for more participation in ESOP companies). The impact of an ESOP on worker outcomes may be more closely tied to the ESOP value as a percent of pay -- i.e. ownership intensity in relationship to one’s economic situation - rather than simply membership in an EOSP plan.

\section{Company treatment of employees}


Both the GSS and the NBER company survey asked a variety of quality of work life questions. Item 2 in Table 1 contains results for ten of those measures. ${ }^{4}$

The national survey data give generally positive results. Shared capitalism employees are more likely to say that they are treated with respect, management-employee relations are good, promotions are handled fairly, and worker safety is a high priority with management. A measure that reflects directly on the "management by stress" theories is the employee's perception of stress at work, which is not significantly related to the shared capitalism index. In additional calculations not presented here, we examined the positive worker safety result using breakdowns by type of shared capitalism program. In contrast to studies that found no consistent relationship between employee ownership and worker safety (Rooney, 1992; Rhodes and Steers, 1981), our data show that employee-owners as well as profit-sharers are more likely to report that worker safety is a high priority with management.

The NBER data, in contrast, show consistently positive results for shared capitalism and company treatment. Shared capitalism is positively linked to perceptions that the company shares success with employees and is fair to employees, and to grades workers give to the company on sharing information, trustworthiness, and employee relations. These positive associations become smaller in magnitude but remain positive and highly significant when controlling for several human resource policies (being in an EI team, training, and job security). Disaggregating by type of shared capitalism program in Table B-2, profit sharing and gainsharing eligibility are strongly linked to perceptions that the company shares and is fair to employees (cols. 1-2), while

\footnotetext{
${ }^{4}$ The GSS contains other quality of work life measures which we also analyzed. The results (available on request) were broadly similar across these measures, generally showing positive relationships to profit sharing but not to the other shared capitalism measures.
} 
profit sharing intensity is strongly associated with all three of the grades (cols. 3-5).

Employee-owners are also more likely to say the company shares with employees (col. 1), while the size of the ownership stake is a strong predictor of each of the five measures.

Comparisons among employee ownership types show an interesting disparity. Having more employer stock in a 401(k) plan is positively linked to each of the measures, while ESOP membership and stake are positively associated with perceptions that the company shares with employees, but ESOP membership is negatively associated with the other four perceptions of company treatment both with and without company fixed effects. This is consistent with the finding that ESOP members are less likely to be satisfied with their participation in decisions.

\section{Supervision}

Since incentive programs are one way to reduce the principal-agent problem when supervision is difficult or costly, we expect less supervision in shared capitalist environments. In addition, we expect supervisors to be more concerned with maintaining a cooperative atmosphere that helps solve the free rider problem than with watching workers work.

The GSS asked respondents for views of their supervisors, while the NBER survey asked about the degree of supervision. As seen in item 3 of Table 1, shared capitalism employees are more likely to see their supervisors as helpful and caring, while they are less likely to report that

they are closely supervised both before and after controlling for other HR policies. When broken out by type of shared capitalism program in Table B-3, the strongly significant result is that ESOP members have greater freedom from supervision (col. 1). Most of the coefficients on other programs are positive, which indicates that each program contributes to the strongly positive shared capitalism coefficient in Table 2.

\section{Training}


The national GSS data in Table 2 show that shared capitalism employees are more likely to say they have the training opportunities they need. The NBER data show that they report a higher likelihood of formal job training in the past year, greater hours of training, and higher levels of informal job training from fellow workers, with and without controls for participation in an EI team and job security. The breakdowns by plan in Table B-3 show that both training and hours of training are higher among workers with profit sharing and employee owners, and are also positively linked to size of gain sharing bonus and employee ownership stake. But training is negatively related to the size of stock option value from future potential profits (cols. 2-3). Among the types of employee ownership, training and training hours are highest among ESOP participants and those with 401(k) employer stock.

The pattern of coefficients is quite different for informal job training from coworkers, which suggests that informal job training often substitutes for formal training. Both stock option holding and the size of the stake are positively linked to informal training (Table B-3, col. 4). Also, while ESOP members are more likely to get formal training, they are less likely to get informal training. Gainsharing is positively associated with informal training, as is the size of a workers' higher profit-sharing stake. The broad range of associations between shared capitalism and formal and informal training suggest that training is complementary with shared capitalism.

\section{Pay and benefits}

Table 1 shows that pay tends to be higher among employees with greater shared capitalist forms of pay in both the national and NBER company data. Employees in the NBER company data set with greater shared capitalism are more likely to say that their fixed pay is as at least equal to market and rate their total compensation as higher than market and to rate their company as higher on wages than others. Employees in the national shared capitalism survey are more likely 
to feel they are paid what they deserve. Employees with greater shared capitalism in both datasets rate their companies as better on fringe benefits. The NBER results are not affected by the inclusion of several human resource policies. When the shared capitalism programs are broken out in Table B-4, most of the shared capitalism types are associated with higher fixed pay, though the gainsharing bonus intensity and employee ownership stake are inversely related to pay. There are few associations with the employee's rating of fixed pay relative to market (col. 2), but total compensation relative to market is higher among gainsharers and those with higher profit sharing benefits when they receive profit sharing, have bigger profit sharing bonuses, and are employee-owners through ESPP's and 401(k) plans (cols. 4-5). The pay and benefit results indicate that shared capitalism does not generally substitute for fixed pay or other benefits. This rejects a simple compensating differences story of shared capitalist modes of pay, although the higher pay may help compensate for greater effort or other forms of costly behavior.

\section{Co-worker Relations}

Does shared capitalism help or hurt relations with fellow workers? Employees with greater shared capitalism in the GSS dataset are more likely to report that their co-workers can be relied on for help when needed, and that their co-workers take a personal interest in them. Such helpfulness and interest presumably make work more pleasant and increase employee welfare directly, but may also lay the foundation for cooperation among employees that can increase workplace performance (explored in the companion papers by Freeman, Kruse, and Blasi 2008, and Blasi et al. 2008).

6. Job Security

Shared capitalism is associated with greater job security. Employees higher in the shared capitalist index report a lower likelihood of losing their jobs, and in the national data they report a 
lower likelihood of being laid off in the past year. The NBER results are maintained when controlling for participation in an EI team and receipt of training. When broken out by shared capitalism policy, both profit sharing eligibility and the size of the profit share are linked to greater

job security (Table B-5, col. 1). Owning employer stock, and the size of the ownership stake and stock option value, are also positively associated with job security. The breakdowns by type of employee ownership indicate that job security is highest among ESOP participants and those holding 401(k) employer stock, and those with greater holdings in both of those plans. The findings that job security is greater for employee-owners than for other workers is consistent with prior research on the employment stability and company survival of employee ownership firms (Blair et al., 2000, Park et al., 2004).

\section{Job satisfaction}

Job satisfaction is positively linked to the shared capitalism index in both the national and NBER company data, but the result is statistically significant only in the NBER data. This NBER result disappears, however, when controlling for the human resource policies. The strong association between shared capitalism and these human resource policies indicates that there may be important complementarities, which we explore in Table 2. When the policies are broken out in Table B-5, job satisfaction is positively associated with the size of the profit sharing and gainsharing bonuses, and with participation in an ESOP when company fixed effects are removed (col. 2). The positive ESOP result on job satisfaction presumably reflects the positive effects of ESOP membership on training, freedom from supervision, rating of benefits, and job security overpowering ESOP participants' lower satisfaction with participation in decisions (Table B-1) and their lower ratings for the company on several measures (Table B-2). 
Both theory and evidence support the idea that there may be important complementarities among human resource policies in affecting workplace performance (e.g., Levine and Tyson, 1990; Huselid, 1995; Ichniowski et al., 1996). These complementarities may also affect employee outcomes: for example, job satisfaction may be increased more by combining shared capitalism with employee involvement and training than by the sum of the policies in isolation.

Measurement of high-performance human resource policies varies among studies. One analysis divides them into seven broad categories: group incentive pay, teamwork/employee involvement, training, employment security, information sharing, flexible job assignment, and recruitment and selection (Ichniowski et al., 1997). The NBER surveys contain measures of each of these, but not for every company. ${ }^{5}$ For our investigation of complementarities, we created a human resource policy index that gives one point each for being in an employee involvement team, receiving formal training in the past 12 months, and having high job security, and we then interact this index with the shared capitalism index. ${ }^{6}$

Shared capitalism may also interact with supervision in affecting employee outcomes. Shared capitalist policies may, as noted, help substitute for close supervision of workers by providing greater incentives for workers to work hard and monitor their co-workers. The finding that shared capitalism is associated with greater freedom from supervision lends support to this idea (Table 1). When shared capitalist policies are combined with close supervision, however, the results may be negative. If workers are not given much latitude in how they do their work, shared

\footnotetext{
${ }^{5}$ Flexible job assignment was measured as job rotation at six companies, and rigorous selection was measured at one large company.

6 We also experimented with indices using measures of information sharing, job rotation, and rigorous selection, producing a similar pattern of results. Here we use the index based only on employee involvement, training, and job security since the sample sizes are smaller for job rotation and rigorous selection, and the grade of the company on sharing information reflects an employee evaluation of the policy's success (highly correlated with evaluations of the company on other dimensions), rather than the existence of a policy.
} 
capitalist policies may serve mainly to shift financial risk to workers, resulting in more negative worker behaviour and attitudes. At a minimum, combining shared capitalism with close supervision sends a mixed message to employees: "We want you to work harder and be more committed to the company because of your (profit share/employer stock/stock options), but we're still going to keep a close eye on you." Workers may not respond well to this mixed message.

Table 2 assesses interactions between the shared capitalism index and other workplace policies to assess possible complementarities in effects on employee attitudes. The statistical analysis shows that shared capitalism interacts with high performance policies and supervision in affecting a number of employee outcomes. ${ }^{7}$ The interaction with high performance policies shows that employees are especially likely to have high participation, and to be satisfied with their participation, when they are covered by both shared capitalist and high performance policies (col. 3). The interaction is also positive with informal training and overall job satisfaction. The interaction is negative, however, on perceptions of company sharing, fairness, and benefits; the coefficients indicate that shared capitalism has a positive effect both for those with and without high performance policies, but has a more positive effect for those who are not also covered by high performance policies.

The pattern is more straightforward with respect to supervision: the combination of shared capitalism with close supervision produces a more negative outcome in almost every case (col. 5). The main effect of close supervision is generally positive (col. 4), indicating that in the absence of shared capitalism, having close supervision may often be a good thing (e.g., giving workers a

\footnotetext{
7 When the high performance index included the outcome being predicted, that item was deleted from the high performance index (e.g., employee involvement was deleted from the high performance index in predicting participation in an employee involvement team).
} 
better sense of what they are supposed to do). But the main effect is counteracted in most cases, however, by the negative shared capitalism interaction-e.g., the predicted overall effect of increased supervision on perceptions of company fairness is negative whenever the shared capitalism index is 2 or greater.

The contingent effects of shared capitalism on job satisfaction are illustrated in Figure 1, which uses the regression results from Table 2. When workers are covered by high performance policies and have low or average levels of supervision, the effects of increased shared capitalism are positive (top two lines). When they are not covered by high-performance policies, and/or are very closely supervised, the effects of shared capitalism are slightly or very negative (bottom four lines). While the overall relationship between shared capitalism and job satisfaction is close to zero after controlling for other policies (Table 1), these results illustrate that the other policies can greatly condition the effects of shared capitalism.

\section{CONCLUSION}

Do workers gain by sharing? The evidence generally supports an answer of "yes", with some caveats. Both the national and NBER company data indicate that shared capitalism is positively linked to participation in decisions, evaluations of company climate and employee treatment, perceptions of helpfulness by supervisors, lower levels of supervision, and higher levels of training, pay and benefits, job security, and job satisfaction. Almost all of these relationships remain strong when controlling for other human resource policies. This rejects the "management by stress" theories of work innovation.

When broken out by type of shared capitalist program, profit sharing was most consistently linked to the positive outcomes, although gainsharing, stock options, and employee ownership also 
affect some outcomes positively. In many cases the positive effect was tied to simply being covered by a policy (e.g., being eligible for profit sharing, or being an employee-owner), but there were also many cases in which the effect was tied to the size of the financial stake involved (size of most recent bonus, or value of employer stock or stock options).

Estimated negative relations between some aspects of shared capitalism and some outcomes are also informative about how this form of financial sharing operates. In particular, while being a member of an ESOP was linked to a number of positive outcomes (participation in decisions, perception that the company shares, freedom from supervision, formal training, pay and benefit levels, job security, and job satisfaction), ESOP members also had lower satisfaction with participation in decisions and lower ratings of the company on fairness, trustworthiness, and employee relations. One possible reason is that employee-owners may be frustrated by unfulfilled desires for greater participation in decisions (above the higher levels they already have). Another possible reason is that some ESOP accounts have too little stock to be meaningful and some employees may have negative attitudes when they are called owners but have very little ownership. The importance of the ownership stake is highlighted by the finding that satisfaction with participation rises with the value of employee-owned stock as a percent of pay. The dynamics of employee ownership may work differently for ESOPs than for other forms of ownership: it is the only form where all eligible workers are automatically enrolled and called owners even with miniscule accounts.

Finally, our data reveals potentially important complementarities of shared capitalism with other workplace policies, particularly with high performance work policies and closeness of supervision. Those who are covered by the combination of high-performance policies with shared capitalism are most likely to report high participation in decisions, satisfaction with participation, 
and overall job satisfaction. The combination of close supervision with shared capitalism, however, has negative effects on almost every outcome.

Overall, our findings are consistent with theories that stress the linkage between group incentive pay systems and other labor and personnel relations policies. Taken as a package, a high performance work system involves greater participation, higher quality of supervision, more formal training, better wages and benefits, higher job satisfaction, and better job security. Employers who are concerned about company performance, and workers who are concerned about the quality of their working life, have reasons to be interested in this package. Our findings that shared capitalist programs are often associated with these policies and outcomes indicate that there is good potential for workers to gain through sharing. 


\section{Bibliography}

Akerlof, George. 1982. "Labor Contracts as Partial Gift Exchange," Quarterly Journal of Economics, Vol. 97, pp. 543-569.

Azfar, Omar, and Stephan Danninger. 2001. "Profit-Sharing, Employment Stability, and Wage Growth," Industrial \& Labor Relations Review, Vol. 54 (3), April, pp. 619-30.

Bakan, Ismail, Yuliani Suseno, Ashly Pinnington, and Arthur Money. 2004. "The Influence of Financial Participation and Participation in Decision-making on Employee Job Attitudes," International Journal of Human Resource Management, Vol. 15(3), May, pp. 587-616.

Bartholomew, David, J. Galbraith, Irini Moustkaki, Fionay Steele. 2002. The Analysis and Interpretation of Multivariate Data for Social Scientists. Chapman and Hall/CRC.

Bartholomew, David. 1996. The Statistical Approach to Social Measurement Academic Press.

Blair, Margaret, Douglas Kruse, and Joseph Blasi. 2000. “Is Employee Ownership an Unstable Form? Or a Stabilizing Force?" in Thomas Kochan and Margaret Blair, eds., The New Relationship: Human Capital in the American Corporation. Washington, D.C.: The Brookings Institution.

Black, Sandra, Lisa Lynch, and Anya Krivelyova. 2004. "How Workers Fare When Employers Innovate," Industrial Relations, Vol. 43 (1), pp. 44-66.

Blasi, Joseph. 1988. Employee Ownership: Revolution or Ripoff? New York: Basic Books.

Blasi, Joseph, Michael Conte and Douglas Kruse. 1996. "Employee Ownership and Corporate Performance Among Public Corporations,” Industrial and Labor Relations Review, Vol. 50, No. 1, October, pp. 60-79.

Blasi, Joseph, Richard Freeman, Chris Mackin, and Douglas Kruse. 2008. "Creating a Bigger Pie? The Effects of Employee Ownership, Profit Sharing, and Stock Options on Workplace Performance." Presented at NBER/Russell Sage Foundation conference, New York, NY, October 2006.

Blasi, Joseph, Douglas Kruse, and Aaron Bernstein. 2003. In the Company of Owners: The Truth About Stock Options (And Why Every Employee Should Have Them). New York: Basic Books.

Blasi, Joseph, Douglas Kruse, and Harry M. Markowitz. 2008. "Risk and Lack of Diversification under Employee Ownership and Shared Capitalism. ” Presented at NBER/Russell Sage Foundation conference, New York, NY, October 2006.

Bonin, J.P., and Louis Putterman. 1987. Economics of Cooperation and the Labor-Managed 
Economy. New York: Harwood Academic Publishers.

Brown, Sarah, and John G. Sessions. 2003. "Attitudes, Expectations, and Sharing," Labour, Vol. 17, No. 4, pp. 543-569.

Buchele, Robert, Douglas Kruse, Loren Rodgers, and Adria Scharf. 2008. "Show Me the Money: The Wealth Impact of Shared Capitalism.” Presented at NBER/Russell Sage Foundation conference, New York, NY, October 2006.

Budd, John. 2008. “Does Employee Ignorance Undermine Shared Capitalism” Presented at NBER/Russell Sage Foundation conference, New York, NY, October 2006.

Cappelli, Peter, and David Neumark. 2004. "External Churning and Internal Flexibility: Evidence on the Functional Flexibility and Core-Periphery Hypotheses," Industrial Relations, Vol. 43 (1), pp. 148-182.

Carberry, Edward. 2008. "An Analysis of Social Stratification in Companies with Shared Capitalism.” Presented at NBER/Russell Sage Foundation conference, New York, NY, October 2006.

Conyon, Martin and Richard Freeman "Shared Modes of Compensation and Firm Performance: UK Evidence”, Chapter 3 in Seeking a Premiere League Economy, Richard Blundell, David Card and Richard Freeman (eds). Chicago: Univ of Chicago Press, pp 109-146. NBER WP \#8448, August 2001.

Craig B. and J. Pencavel. 1992. "The Behavior of Worker Cooperatives: The Plywood Companies of The Pacific Northwest," American Economic Review, 82, 1083-1105.

-----. 1993. "The Objectives of Worker Cooperatives," Journal of Comparative Economics, Vol. 17(2), June, pp. 288-308.

-----. 1995. "Participation and Productivity: A Comparison of Worker Cooperatives and Conventional Firms in The Plywood Industry," Brookings Papers on Economic Activity, 212-160.

Dube, Arindrajit and Richard Freeman 2001. "Shared Compensation Systems and Decision-Making in the US Job Market”, Incomes and Productivity in North America, Papers from the 2000 Seminar. (Washington, DC: Secretariat of the Commission for Labor Cooperation).

Estrin, Saul, and Derek C. Jones. 1992. "The Viability of Employee-Owned Firms: Evidence from France," Industrial \& Labor Relations Review, Vol. 45 (2). p 323-38, January.

Freeman, R and Joel Rogers. 1999. What Workers Want. New York: Russell Sage and Cornell University Press. 
Freeman, Richard, Douglas Kruse, and Joseph Blasi. 2008. "Worker Responses to Shirking under Shared Capitalism.” Presented at NBER/Russell Sage Foundation conference, New York, NY, October 2006.

Grunberg, Leon, Sarah Moore, and Edward Greenberg. 1996. “The Relationship of Employee Ownership and Participation to Workplace Safety,” Economic and Industrial Democracy, Vol. 17(2), May, pp. 221-241.

Handel, Michael, and Maury Gittleman. 2004. "Is There A Wage Payoff to Innovative Practices?" Industrial Relations, Vol. 43 (1), pp. 67-97.

Handel, Michael, and David Levine. 2004. "Editors' Introduction: The Effects of New Work Practices on Workers," Industrial Relations, Vol. 43 (1), pp. 1-43.

Harden, Erika, Douglas Kruse, and Joseph Blasi. 2008. "Who Has a Better Idea: Innovation, Shared Capitalism, and Human Resource Policies.” Presented at NBER/Russell Sage Foundation conference, New York, NY, October 2006.

Heywood, John, Uwe Jirjahn, and Georgi Tsertsvadze, "Getting Along with Colleagues - Does Profit Sharing Help or Hurt?" Kyklos, Vol. 58, No. 4, pp. 557-573.

Ichniowski, Casey, Thomas Kochan, David Levine, Craig Olson, and George Strauss. 1996. "What Works at Work: Overview and Assessment," Industrial Relations, 35(3) 299-333.

Ichniowski, Casey, Kathryn Shaw, and Giovanni Prennushi. 1997. "The Effects of Human Resource Practices on Productivity: A Study of Steel finishing Lines," American Economic Review, Vol. 87, No. 3, June, pp. 291-313.

Kalmi, Pamu, Andrew Pendleton, and Erik Poutsma. 2005. "Financial Participation and Performance in Europe," Human Resource Management Journal, Vol. 15, No. 4, pp. 545-67.

Kardas, Peter; Adria L. Scharf; and Jim Keogh. 1998. "Wealth and Income Consequences of ESOPs and Employee Ownership: A Comparative Study from Washington State," Journal of Employee Ownership Law and Finance. Vol. 10, No. 4, Fall.

Keef, Stephen P. 1998. “The Causal Association between Employee Share Ownership and Attitudes: A Study Based on the Long Framework,” British Journal of Industrial Relations, Vol. 36(1), March, pp. 73-82.

Kruse, Douglas. 1984. Employee Ownership and Employee Attitudes: Two Case Studies. Norwood, PA: Norwood Editions.

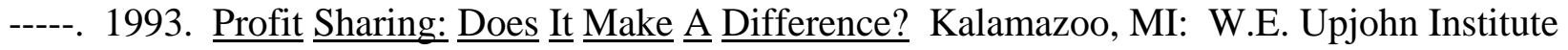


for Employment Research.

-----. 1998. "Profit Sharing and the Demand for Low-Skill Workers," in Richard Freeman and Peter Gottschalk, eds., Generating Jobs: Increasing the Demand for Low-Skill Workers. New York: Russell Sage Foundation.

-----. 2002. “Research Evidence on Prevalence and Effects of Employee Ownership,” Testimony before the Subcommittee on Employer-Employee Relations, Committee on Education and the Workforce, U.S. House of Representatives, February 13.

-----, and Joseph Blasi. 1997. "Employee Ownership, Employee Attitudes, and Firm Performance: A Review of the Evidence," in The Human Resources Management Handbook, Part $\underline{1}$. Edited by David Lewin, Daniel J.B. Mitchell, and Mahmood A. Zaidi. Greenwich, CT.: JAI Press.

Kruse, Douglas, Joseph Blasi, and Rhokeun Park. 2008. "Shared Capitalism in the U.S. Economy: Prevalence, Characteristics, and Employee Views of Financial Participation in Enterprises.” Presented at NBER/Russell Sage Foundation conference, New York, NY, October 2006.

Levine, David, and Laura D'Andrea Tyson. 1990. "Participation, Productivity, and the Firm's Environment," in Alan Blinder, ed., Paying For Productivity: A Look at the Evidence. Washington, D.C.: Brookings Institution.

Long, R.L. 1981. "The Effects of Formal Employee Participation in Ownership and Decision Making on Perceived and Desired Patterns of Organizational Influence: A Longitudinal Study," Human Relations, Vol. 34, pp. 847-876.

-----. 1982. "Worker Ownership and Job Attitudes: A Field Study," Industrial Relations, Vol. 21, pp. 196-215.

Logue, John, and Jacquelyn Yates. 2001. The Real World of Employee Ownership. Ithaca, NY: Cornell University Press.

Pendleton, Andrew, Nicholas Wilson, and Mike Wright. 1998. "The Perception and Effects of Share Ownership: Empirical Evidence from Employee Buy-outs," British Journal of Industrial Relations, Vol. 36(1), March, pp. 99-123.

Quarrey, M., \& Rosen, C. 1993. Employee Ownership and Corporate Performance. Oakland, CA: National Center for Employee Ownership.

Renaud, Stephane, Sylvie St-Onge, and Michael Magnan. 2004. "The Impact of Stock Purchase Plan Participation on Workers' Individual Cash Compensation," Industrial Relations, Vol. 43 (1), pp. 120-147. 
Rhodes, S.R., and R.M. Steers. 1981. "Conventional vs. Worker-Owned Organizations," Relations, Vol. 24, pp. 1013-1035.

Robinson, Andrew, and Hao Zhang. 2005. "Employee Share Ownership: Safeguarding Investments in Human Capital," British Journal of Industrial Relations, Vol. 43(3), September, pp. 469-488.

Rooney, Patrick. "Employee Ownership and Worker Participation: Effects on Health and Safety," Economic Letters, Vol. 39, pp. 323-328.

Scharf, Adria, and Christopher Mackin. 2000. "Census of Massachusetts Companies with Employee Stock Ownership Plans (ESOPs)." Boston: Commonwealth Corporation.

Spector, Paul E. 1992 Summated Rating Scale Construction: An Introduction, Sage, London, Quantitative Applications in Social Sciences, 82

Weitzman, Martin L. 1984. The Share Economy. Cambridge, MA: Harvard University Press.

-----, and Douglas Kruse. 1990. "Profit Sharing and Productivity,” in Alan Blinder, ed., Paying For Productivity: A Look at the Evidence. Washington, D.C.: Brookings Institution.

Wilson, Nicholas, and Michael Peel. 1991. “The Impact on Absenteeism and Quits of Profit-Sharing and Other Forms of Employee Participation,” Industrial and Labor Relations Review, Vol. 44(3), April, pp. 454-468.

Winther, Gorm, and Richard Marens. 1997. "Participatory Democracy May Go A Long Way: Comparative Growth Performance of Employee Ownership Firms in New York and Washington States," Economic and Industrial Democracy, Vol. 18(3), August, pp. 393-422. 


\section{APPENDIX A: Variable definitions and descriptive statistics}

\section{COMPENSATION}

Shared capitalism index (GSS): 8-point index with one point each for profit sharing eligibility, gain sharing eligibility, owning any company stock, holding any stock options, receiving a profit sharing bonus in the past year, receiving a gain sharing bonus in the past year, having an above-median profit- and gain sharing bonus as a percent of pay, and having an above-median company stock holding as a percent of pay. Mean=1.48, s.d.=2.14, n=1919

Shared capitalism index (NBER): 10-point index with all items in GS index, plus one point each for receiving a stock option grant in the past year, and having above-median stock option holdings as a percent of pay. Mean=3.60, s.d. $=2.65, \mathrm{n}=40522$

Profit sharing (GSS and NBER): "In your job are you eligible for any type of performance-based pay, such as individual or group bonuses, or any type of profit-sharing? What does the size of these performance-based payments depend on? Company profits or performance" ( $0=$ no, $1=$ yes), GSS mean=.372, $n=2184$, NBER mean=.713, $n=41018$

Profit sharing as \% of pay (GSS and NBER): If "yes" to profit sharing, answer to "What was the approximate total dollar value of the payment(s) you received [in the most recent year of bonuses]?" divided by basepay+overtime, otherwise 0. GSS mean=.024, s.d.=.066, $\mathrm{n}=1944$, NBER mean=.068, s.d.=.124, $\mathrm{n}=40485$

Gainsharing (GSS and NBER): "In your job are you eligible for any type of performance-based pay, such as individual or group bonuses, or any type of profit-sharing? What does the size of these performance-based payments depend on? Workgroup or department performance" (0=no, $1=$ yes), GSS mean=.257, $\mathrm{n}=2184$, NBER mean=.207, $\mathrm{n}=41023$

Gainsharing as \% of pay (GSS and NBER): If "yes" to gainsharing, answer to "What was the approximate total dollar value of the payment(s) you received [in the most recent year of bonuses]?" divided by basepay+overtime, otherwise 0 . GSS mean=.017, s.d. $=.061$, $\mathrm{n}=2013$, NBER mean=.033, s.d.=.106, $\mathrm{n}=40767$

Individual bonus (GSS and NBER): "In your job are you eligible for any type of performance-based pay, such as individual or group bonuses, or any type of profit-sharing? What does the size of these performance-based payments depend on? Individual performance" (0=no, 1=yes). GSS mean=.290, $n=2184$, NBER mean=.290, $n=41019$

Individual bonus as \% of pay (NBER): If "yes" to individual bonus, answer to "What was the approximate total dollar value of the payment(s) you received [in the most recent year of bonuses]?" divided by basepay+overtime, otherwise 0 . Mean=.050, s.d.=.125, $n=40547$ 
Hold employer stock (GSS): "Do you own any shares of stock in the company where you now work, either directly or through some type of retirement or stock plan?" $(0=$ no, $1=$ yes), mean=.212, $\mathrm{n}=2202$

Employer stock as \% of pay (GSS): If "yes" to "hold employer stock," answer to "Please give a general estimate of how much cash you would get if all this stock were sold today?" divided by annual earnings, otherwise 0 , mean $=.111$, s.d. $=.977, \mathrm{n}=2186$

Hold employer stock (NBER): Any employer stock held through ESOP, Employee Stock Purchase Plan, 401(k), exercised stock options, or open market purchases ( $0=$ no, $1=$ yes), mean $=.640, \mathrm{n}=41206$

Employer stock as \% of pay (NBER): If "yes" to "Hold employer stock," the sum of answers to questions about value of stock held in different plans, divided by basepay+overtime, otherwise 0. NBER mean $=.398$, s.d. $=.808, \mathrm{n}=40367$

Hold stock options (GSS and NBER): "Do you currently hold any stock options in your company (vested or unvested)?" ( $0=$ no, $1=$ yes), GSS mean=.123, n=2188, NBER mean=.219, $\mathrm{n}=41166$.

Stock options as \% of pay (NBER): If "yes" to "Hold stock options," the sum of answers to questions about value of vested and unvested stock, divided by basepay+overtime, otherwise 0 . NBER mean=.395, s.d. $=1.490, \mathrm{n}=40922$

ESOP (NBER): Participant in ESOP (0=no, 1=yes), mean=.081, n=41109

ESOP stock as \% of pay (NBER): Employer stock held in ESOP, divided by basepay+overtime, otherwise 0 , mean $=.067$, s.d. $=.417, \mathrm{n}=41002$

ESPP (NBER): Hold stock purchased through Employee Stock Purchase Plan ( $0=$ no, $1=$ yes), mean=.176, $\mathrm{n}=41169$

ESPP stock as \% of pay (NBER): Employer stock held in Employee Stock Purchase Plan, divided by basepay+overtime, otherwise 0 , mean $=.078$, s.d. $=.304, n=41168$

401(k) stock (NBER): Hold employer stock in 401(k) plan ( $0=$ no, $1=y e s)$, mean=.335, $n=40885$

401(k) stock as \% of pay (NBER): Employer stock held in 401(k) plan, divided by basepay+overtime, otherwise 0 , mean $=.189$, s.d. $=.525, \mathrm{n}=40730$

Stock from exercised options as \% of pay (NBER): Employer stock held from exercised options, divided by basepay+overtime, otherwise 0 , mean=.052, s.d. $=.396, n=40956$ 
Stock from exercised options (NBER): Hold employer stock from exercised options (0=no, $1=$ yes), mean=.050, $\mathrm{n}=41032$

Open mkt. stock as \% of pay (NBER): Employer stock purchased on open market, divided by basepay+overtime, otherwise 0 , mean=.019, s.d.=.165, $n=41144$

Open mkt. stock (NBER): Hold stock purchased on open market ( $0=$ no, $1=y e s)$, mean $=.073, \mathrm{n}=41145$

\section{EMPLOYEE PARTICIPATION IN DECISIONS}

Lot of say on job (GSS): "I have a lot of say about what happens on my job" (1-4 scale, $1=$ strongly disagree, $4=$ strongly agree), mean=2.83, s.d. $=.88, \mathrm{n}=2204$

Make decisions with others (GSS): "In your job, how often do you take part with others in making decisions that affect you?" (1-4 scale, $1=$ never, $4=$ often), mean=3.08, s.d.=.93, $\mathrm{n}=2211$

Help set way things done on job (GSS): "How often do you participate with others in helping set the way things are done on your job?" (1-4 scale, 1=never, 4=often), mean $=3.14$, s.d. $=.92, n=2210$

Freedom in doing work (GSS): "I am given a lot of freedom to decide how to do my own work" (1-4 scale, $1=$ not at all true, $4=$ very true) , mean=3.31, s.d. $=.85, \mathrm{n}=2208$

Involved in job decisions (NBER): "How much involvement and direct influence do YOU have in: Deciding HOW to do your job and organize the work" (1-4 scale, 1=none, 4=a lot), mean=3.27, s.d. $=.87, n=40750$

Involved in department goals (NBER): "How much involvement and direct influence do YOU have in: Setting GOALS for your work group or department" (1-4 scale, 1=none, 4=a lot), mean=2.59, s.d. $=1.04, \mathrm{n}=40594$

Involved in company decisions (NBER): "How much involvement and direct influence do YOU have in: Overall company decisions" (1-4 scale, 1=none, 4=a lot), mean=1.71, s.d. $=.86, \mathrm{n}=40520$

In EI team (NBER): " Some companies have organized workplace decision-making in ways to get more employee input and involvement. Are you personally involved in any team, committee or task force that addresses issues such as product quality, cost cutting, productivity, health and safety, or other workplace issues?" ( $0=$ no, $1=y e s)$, mean=.35, $\mathrm{n}=40122$

Satisfied with participation (NBER): "Overall, how satisfied are you with the influence you have in company decisions that affect your job and work life?" (1-4 scale, 1=not at all 
satisfied, 4=very satisfied), mean=2.61, s.d.=.85, n=40545

\section{SUPERVISION}

Supervisor helpful (GSS): "My supervisor is helpful to me in getting the job done" (1-4 scale, $1=$ not at all true, 4=very true), mean=3.26, s.d.=.88, $n=2197$

Supervisor cares (GSS): "My supervisor is concerned about the welfare of those under him or her" (1-4 scale, $1=$ not at all true, 4=very true), mean=3.26, s.d.=.88, $\mathrm{n}=2185$

Free from supervision (NBER): "Are you closely supervised, or do you work fairly independently of close supervision?" (0-10 scale, $0=$ closely supervised, $10=$ independent of close supervision), mean $=6.65$, s.d. $=2.63, \mathrm{n}=40845$

\section{COMPANY TREATMENT OF EMPLOYEES}

Treated with respect (GSS): "At the place where I work, I am treated with respect" (1-4 scale, $1=$ strongly disagree, 4=strongly agree), mean=3.27, s.d.=.68, n=2209

Mgt.-ee relations (GSS): "In general, how would you describe relations in your work place between management and employees?" (1-5 scale, $1=$ very bad, 5=very good), mean=3.95, s.d. $=.99, \mathrm{n}=2205$

Promotions handled fairly (GSS): "Promotions are handled fairly" (1-4 scale, $1=$ not at all true, $4=$ very true), mean=2.84, s.d. $=.98, \mathrm{n}=2083$

Worker safety is high priority (GSS): "The safety of workers is a high priority with management where I work" (1-4 scale, $1=$ not at all true, $4=$ very true), mean=3.31, s.d.=.70, $n=2194$

Stress (GSS): "How often do you find your work stressful?" (1-5 scale, 1=always, $5=$ never), mean=3.08, s.d.=1.03, $\mathrm{n}=2209$

Employees share when co. does well (NBER): "When the company does well, employees share the benefits" (1-7 scale, 1=strongly disagree, 7=strongly agree), mean $=5.00$, s.d. $=1.78, \mathrm{n}=40676$

Company fair to employees (NBER): "Overall, this company is fair to its employees" (1-7 scale, $1=$ strongly disagree, $7=$ =strongly agree), mean=4.75, s.d. $=1.71, \mathrm{n}=40632$

Co. grade on ee. relations (NBER): "If you were to rate how well this company takes care of workers on a scale similar to school grades, what grade would you give in these areas? Overall relations with employees" ( $0-4$ scale, $0=F, 4=A$ ), mean=2.45, s.d. $=1.07, n=40464$

Co. grade on sharing info (NBER): "If you were to rate how well this company takes 
care of workers on a scale similar to school grades, what grade would you give in these areas? Sharing information with employees" ( $0-4$ scale, $0=F, 4=A)$, mean=2.44, s.d. $=1.11$, $n=40523$

Co. grade on trustworthy (NBER): "If you were to rate how well this company takes care of workers on a scale similar to school grades, what grade would you give in these areas? Trustworthiness in keeping its promises" ( $0-4$ scale, $0=F, 4=A)$, mean $=2.33$, s.d. $=1.15, \mathrm{n}=40385$

\section{TRAINING}

Training opportunities (GSS): "I have the training opportunities I need to perform my job safely and competently" (1-4 scale, $1=$ not at all true, $4=$ very true), mean=3.48, s.d.=.74, $n=2204$

Formal training (NBER): "In the last 12 months have you received any formal training from your current employer, such as in classes or seminars sponsored by the employer?" $(0=$ no, $1=$ yes $)$, mean $=.564, \mathrm{n}=40460$

Training hours (NBER): If "yes" to formal training, answer to "About how many hours of formal training have you received in the last 12 months? If "no" to formal training, coded as 0 . Mean $=17.80$, s.d. $=40.38, n=39426$

Informal training (NBER): "To what extent have fellow employees taught you job skills, problem solving, short cuts, or other ways to improve your work, on an informal basis?" (1-4 scale, $1=$ not at all, $4=$ to a great extent), mean=2.89, s.d.=.85, $\mathrm{n}=40651$

\section{PAY AND BENEFITS}

Yearly earnings (GSS): Total yearly earnings from main job (natural $\log$ ) , mean=10.12, s.d. $=1.05, \mathrm{n}=1888$

Paid what you deserve (GSS): "How fair is what you earn on your job in comparison to others doing the same type of work you do?" (1-5 scale, $1=$ much less than what you deserve, $5=$ much more than you deserve), mean=3.43, s.d. $=.86, \mathrm{n}=2171$

Fringe benefits good (GSS): "My fringe benefits are good" (1-4 scale, 1=not at all true, $4=$ very true), mean=2.87, s.d. $=1.09, \mathrm{n}=2198$

Fixed pay (NBER): Yearly base pay+overtime (natural log), mean=10.710, s.d.=.783, $n=31162$

Fixed pay difference from mkt. (NBER): "Do you believe your fixed annual wages are higher or lower than those of employees with similar experience and job descriptions in other companies in your region? By what percent is it higher or lower?" mean=-4.76, 
s.d. $=17.10, \mathrm{n}=31793$

Total comp. difference from mkt. (NBER): "Do you believe your total compensation is higher or lower than those of employees with similar experience and job descriptions in other companies in your region? By what percent is it higher or lower?" mean=-2.07, s.d. $=18.81, \mathrm{n}=30440$

Grade of co. on wages (NBER): "If you were to rate how well this company takes care of workers on a scale similar to school grades, what grade would you give in these areas? Paying good wages" (0-4 scale, $0=F, 4=A$ ), mean=2.54, s.d.=1.06, $n=40679$

Grade of co. on benefits (NBER): "If you were to rate how well this company takes care of workers on a scale similar to school grades, what grade would you give in these areas? Giving fair benefits to workers" (0-4 scale, $0=F, 4=A$ ), mean=2.64, s.d. $=1.08, n=40611$

\section{CO-WORKER RELATIONS}

Co-workers can be relied on for help (GSS): "The people I work with can be relied on when I need help.” (1-4 scale, $1=$ not at all true, 4=very true), mean=3.37, s.d.=.75, n=2207

Co-workers take personal interest in me (GSS): “The people I work with take a personal interest in me” (1-4 scale, $1=$ not at all true, $4=$ very true), mean=3.21, s.d.=.82, $\mathrm{n}=2197$

\section{JOB SECURITY}

Not likely to lose job (GSS and NBER): "Thinking about the next twelve months, how likely do you think it is that you will lose your job or be laid off?" (1-4 scale, $1=$ not at all likely, 4=very likely), GSS mean=3.27, s.d. $=.87, \mathrm{n}=2198$, NBER mean=3.09, s.d.=.76, $\mathrm{n}=38510$

Not laid off in past year (GSS): "Were you laid off your main job at any time in the last year?" (0=yes, $1=$ no), mean=.920, $\mathrm{n}=2212$.

\section{JOB SATISFACTION}

GSS measure: "All in all, how satisfied would you say you are with your job?" (1-4 scale, $1=$ not at all satisfied, $4=$ very satisfied), mean=3.27, s.d. $=.80, \mathrm{n}=1656$

NBER measure: "How satisfied are you in your job?" (1-7 scale, 1=completely dissatisfied, $7=$ completely satisfied), mean $=5.04$, s.d. $=1.29, \mathrm{n}=40842$ 


\section{OTHER VARIABLES}

High performance policies: Additive index of:

i) Employee involvement team: "Some companies have organized workplace decision-making in ways to get more employee input and involvement. Are you personally involved in any team, committee or task force that addresses issues such as product quality, cost cutting, productivity, health and safety, or other workplace issues?" ( $0=$ no, $1=$ yes), mean=.347, n=40122

ii) Formal training: "In the last 12 months have you received any formal training from your current employer, such as in classes or seminars sponsored by the employer?" ( $0=$ no, $1=$ yes), mean $=.564, \mathrm{n}=40460$

iii) Job security: "Thinking about the next twelve months, how likely do you think it is that you will lose your job or be laid off?" (coded for scale as $0=$ very likely or fairly likely, $1=$ not too likely or not at all likely), mean=.843, $\mathrm{n}=38510$ Index mean=1.77, s.d.=.86, $\mathrm{n}=37125$

Closely supervised: "Are you closely supervised, or do you work fairly independently of close supervision?" (0-10 scale, $0=$ independent of close supervision, $10=$ closely supervised), mean=3.35, s.d. $=2.63$, $n=40845$ 


\section{APPENDIX B: The shared capitalist thermometer index}

As a first step in assessing the relation of shared capitalism to employee outcomes, we constructed a thermometer-style index of shared capitalism. This index assigns one point each when the worker was covered by any of the shared capitalist forms of compensation about which the survey asked, with additional points for recent bonuses or grants, and for large bonuses or stock holdings. For questions with a continuous numeric answer, we gave the item a value of 1 if the respondent had a value greater than the median value. Because there is no natural ordering of shared capitalist systems in the sense that a firm first introduces profit-sharing, then adds employee ownership, and then gain-sharing, the index is not a Guttman scale. It is a simple summated rating (Bartholomew et al, 2002; Bartholomew, 1996), using dichotomous scoring.

In the GSS, there are eight variables in the index: profit sharing eligibility, gain sharing eligibility, owning any company stock, holding stock options, receiving a profit sharing bonus in the past year, receiving a gain sharing bonus in the past year, having an above-median profit- and gain sharing bonus as a percent of pay, and having an above-median company stock holding as a percent of pay. In the NBER data there are ten variables in the index: all of the above items plus one point each for receiving a stock option grant in the past year, and having above-median stock option holdings (including unvested options if they could be exercised today) as a percent of pay.

Indices of this style have both advantages and disadvantages. On the plus side, they provide a quick and ready measure of the extent of shared capitalist arrangements that makes it easy to compare results across surveys and to summarize the broad thrust of findings. Since our firm surveys covered only firms with some shared capitalist arrangements, the index allows us to differentiate workers with differing degrees of incentive to their firm's programs. On the negative side, the index treats different programs the same even though they potentially have different 
effects on particular outcomes. It postulates a single scale with equal weights rather than using factor analysis or other statistical modelling to obtain weights for given factors. To deal with these problems, we estimated the relationship of the outcomes to the different types of shared capitalism, introduced as dummy or continuous variables in regressions. ${ }^{8}$ Tables B-1 to B-5 give the results of those calculations. By comparing the results in the appendix tables with those in the text, we can assess the loss of information due to the amalgamation of the measures into a single index.

Figure B1 shows the distribution of our shared capitalism index in the GSS. This survey estimates that $40 \%$ of US workers have some form of shared capitalist program. This estimate is close to that obtained by Dube and Freeman in the WRPS. The mean score of the index is $1.48-\mathrm{a}$ figure greatly affected by the substantial number of workers without shared capitalism systems. Conditional on having a program, most workers report scores in the range of 2 to 5 , with $6 \%$ reporting scores of 6 or greater. Figure B2 gives the distribution of the index in the NBER survey data. It also shows a non-normal distribution, with the most common scores as 2 to 4 but a sizeable number of workers scoring 7 or above. There is sufficient variation in the index to differentiate the extent of the shared capitalist "treatment" on workers.

\footnotetext{
${ }^{8}$ There are statistical techniques to deal with the formation of latent variable indices from questions of the sort that we are amalgamating into a single summated rating. See Bartholomew et al. (2002) and Spector (1992).
} 
TABLE 1: Relation of Eight Employee Outcomes to Shared Capitalist Compensation

Each row represents results of separate regression

\begin{tabular}{|c|c|c|c|c|c|c|c|c|}
\hline Dependent variables & \multicolumn{3}{|c|}{$\begin{array}{l}\text { Coeff. (s.e.) of } \\
\text { shared capitalism } \\
\text { Index }\end{array}$} & \multirow[t]{2}{*}{$\begin{array}{l}\text { Job and } \\
\text { demog. }\end{array}$} & \multirow[t]{2}{*}{ El team } & \multirow[t]{2}{*}{ Training } & \multirow[t]{2}{*}{$\begin{array}{l}\text { Job } \\
\text { security }\end{array}$} & \multirow[t]{2}{*}{$\mathrm{N}$} \\
\hline $\begin{array}{l}\text { 1. PARTICIPATION IN DECISIONS } \\
\text { National data }\end{array}$ & & & & & & & & \\
\hline Lot of say about what happens on job (1-4 scale) & 0.064 & *** & $(0.014)$ & $x$ & & & & 1677 \\
\hline Take part with others in making decisions (1-4 scale) & 0.100 & $* * *$ & $(0.015)$ & $x$ & & & & 1680 \\
\hline Participate with others in setting way things are done (1-4 scale) & 0.084 & *** & $(0.015)$ & $x$ & & & & 1679 \\
\hline Lot of freedom to decide how to do work (1-4 scale) & 0.053 & $* \star *$ & $(0.015)$ & $x$ & & & & 1680 \\
\hline \multicolumn{9}{|l|}{ NBER company data } \\
\hline \multirow[t]{2}{*}{ Part. in job decisions (1-4 scale)(ordered probit) } & 0.039 & $* \star *$ & (0.004) & $x$ & & & & 39117 \\
\hline & 0.019 & $* * *$ & (0.005) & $x$ & $x$ & $x$ & $x$ & 35596 \\
\hline \multirow[t]{2}{*}{ Part. in group/dept. goals (1-4 scale)(ordered probit) } & 0.020 & $\star * *$ & (0.004) & $x$ & & & & 38997 \\
\hline & 0.004 & ** & $(0.004)$ & $x$ & $x$ & $x$ & $x$ & 35501 \\
\hline \multirow[t]{2}{*}{ Part. in company decisions (1-4 scale)(ordered probit) } & 0.012 & $* * \star$ & $(0.004)$ & $x$ & & & & 38942 \\
\hline & -0.002 & & $(0.004)$ & $x$ & $x$ & $x$ & $x$ & 35462 \\
\hline \multirow[t]{2}{*}{ In employee involvement team (0-1)(linear prob.) } & 0.020 & $* * *$ & $(0.002)$ & $x$ & & & & 38576 \\
\hline & 0.017 & 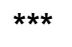 & $(0.002)$ & $x$ & & $\mathrm{x}$ & $\mathrm{x}$ & 35838 \\
\hline \multirow[t]{2}{*}{ Satisfaction with participation (1-4 scale)(ordered probit) } & 0.016 & *** & $(0.004)$ & $x$ & & & & 38964 \\
\hline & -0.002 & & $(0.004)$ & $x$ & $x$ & $x$ & $\mathrm{x}$ & 35494 \\
\hline \multicolumn{9}{|l|}{$\begin{array}{l}\text { 2. COMPANY TREATMENT OF EMPLOYEES } \\
\text { National data }\end{array}$} \\
\hline Am treated with respect at work (1-4 scale)(ordered probit) & 0.029 & * & $(0.015)$ & $x$ & & & & 1679 \\
\hline Mgt-employee relations (1-4 scale)(ordered probit) & 0.036 & $* * *$ & $(0.014)$ & $x$ & & & & 1677 \\
\hline Promotions are handled fairly (1-4 scale)(ordered probit) & 0.042 & $\star \star \star *$ & $(0.014)$ & $x$ & & & & 1610 \\
\hline Worker safety is high priority with mgt. (1-4 scale)(ordered probit) & 0.067 & *** & $(0.015)$ & $x$ & & & & 1671 \\
\hline Lack of stress at work (1-4 scale)(ordered probit) & 0.008 & & $(0.013)$ & $x$ & & & & 1681 \\
\hline \multicolumn{9}{|l|}{ NBER company data } \\
\hline When co. does well, ees. share benefits (1-7 scale)(OLS) & 0.126 & *** & $(0.006)$ & $\mathrm{x}$ & & & & 39065 \\
\hline
\end{tabular}


Co. is fair to ees. (1-7 scale)(OLS)

Grade of co. on sharing info (0-4 scale)(OLS)

Grade of co. on trustworthiness (0-4 scale)(OLS)

Grade of co. on employee relations (0-4 scale)(OLS)

\section{SUPERVISION}

National data

Supervisor is helpful to me (1-4 scale)(ordered probit)

Supervisor cares about welfare of those under him or her (1-4 scale)(ordered probit)

\section{NBER company data}

Freedom from close supervision (0-10 scale)(OLS)

4. TRAINING

National data

Have training opportunities I need

NBER company data

Formal job training in past 12 mos. (0-1)(OLS)

Hours of training in past 12 mos. (Tobit)

Informal job training from co-workers (1-4 scale)(ordered probit)

\section{PAY AND BENEFITS}

\section{National data}

Yearly earnings (natural logarithm)(OLS)

Paid what you deserve (1-5 scale)(ordered probit)

Fringe benefits are good (1-4 scale)(ordered probit)

\begin{tabular}{|c|c|c|c|c|c|c|c|}
\hline 0.104 & 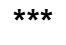 & (0.006) & $x$ & $x$ & $\mathrm{x}$ & $x$ & 35592 \\
\hline 0.063 & *** & $(0.006)$ & $x$ & & & & 39030 \\
\hline 0.038 & *** & (0.006) & $x$ & $x$ & $x$ & $x$ & 35548 \\
\hline 0.023 & $\star \star \star *$ & (0.004) & $x$ & & & & 38932 \\
\hline 0.008 & ** & (0.004) & $x$ & $x$ & $x$ & $x$ & 35452 \\
\hline 0.029 & $\star \star \star *$ & (0.004) & $x$ & & & & 38821 \\
\hline 0.012 & $\star * *$ & (0.004) & $x$ & $x$ & $x$ & $x$ & 35394 \\
\hline 0.023 & *** & (0.004) & $x$ & & & & 38884 \\
\hline 0.008 & ** & (0.004) & $x$ & $x$ & $x$ & $x$ & 35420 \\
\hline 0.038 & $* * *$ & (0.015) & $x$ & & & & 1675 \\
\hline 0.055 & $\star \star \star ~$ & (0.015) & $x$ & & & & 1667 \\
\hline 0.039 & $* * *$ & (0.009) & $x$ & & & & 39488 \\
\hline 0.034 & $* * *$ & (0.009) & $x$ & $x$ & $x$ & $x$ & 35838 \\
\hline 0.045 & $\star \star *$ & (0.016) & $x$ & & & & 1678 \\
\hline 0.019 & $* * *$ & (0.002) & $x$ & & & & 38863 \\
\hline 0.015 & 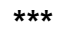 & (0.002) & $x$ & $x$ & & $x$ & 35838 \\
\hline 2.289 & $\star * * *$ & $(0.226)$ & $x$ & & & & 37905 \\
\hline 1.838 & $\star \star \star *$ & $(0.236)$ & $x$ & $x$ & & $x$ & 34974 \\
\hline 0.022 & $* * *$ & (0.004) & $x$ & & & & 39033 \\
\hline 0.009 & $* * *$ & (0.004) & $x$ & $x$ & $x$ & $x$ & 35597 \\
\hline 0.092 & *** & (0.009) & $x$ & & & & 1681 \\
\hline 0.059 & $\star \star \star$ & (0.013) & $x$ & & & & 1841 \\
\hline 0.117 & $\star \star \star *$ & (0.014) & $x$ & & & & 1860 \\
\hline
\end{tabular}




\section{NBER company data}

Fixed pay (natural logarithm)(OLS)

Fixed pay \% diff. from market (OLS)

Total compensation \% diff. from market (OLS)

Grade of co. on wages (0-4 scale)(OLS)

Grade of co. on benefits (0-4 scale)(OLS)

\section{CO-WORKER RELATIONS}

\section{National data}

Co-workers can be relied on for help

Co-workers take personal interest in me

\section{JOB SECURITY}

National data

Not likely to lose job (1-4 scale)(ordered probit)

Not laid off in past year (0-1 dummy)

\section{NBER company data}

Not likely to lose job (1-4 scale)(ordered probit)

\section{JOB SATISFACTION}

National data

Job satisfaction (1-4 scale)(ordered probit)

NBER company data

Job satisfaction (1-7 scale)(OLS)

$\begin{array}{llll}\mathbf{0 . 0 2 3} & * * * & (0.002) & x \\ \mathbf{0 . 0 2 4} & * * * & (0.002) & x \\ 0.094 & & (0.067) & x \\ 0.051 & & (0.070) & x \\ \mathbf{0 . 5 1 1} & * * * & (0.072) & x \\ \mathbf{0 . 4 6 8} & * * * & (0.075) & x \\ \mathbf{0 . 0 2 5} & * * * & (0.004) & x \\ \mathbf{0 . 0 1 8} & * * * & (0.004) & x \\ \mathbf{0 . 0 3 4} & * * * & (0.004) & x \\ \mathbf{0 . 0 2 4} & * * * & (0.004) & x\end{array}$

0.030 ** $(0.015) \quad x$

0.047 *** $(0.015) \quad x$

1680

1675

$\begin{array}{lllllll}\mathbf{0 . 0 4 7} & * * * & (0.015) & \mathrm{X} & & & 1676 \\ \mathbf{0 . 0 1 2} & * \star * & (0.003) & \mathrm{X} & & & 1681 \\ & & & & & & 37052 \\ \mathbf{0 . 0 5 4} & * * * & (0.004) & \mathrm{X} & & & 35838\end{array}$

$\begin{array}{llll}0.022(0.018) & x & 1262\end{array}$

$\begin{array}{llll}0.015 * * & (0.005) \quad x & 39192\end{array}$

$\begin{array}{lllllll}-0.004 & (0.005) & x & x & x & x & 35685\end{array}$

$* p<.10 * * p<.05 * * * p<.01 \quad$ Coefficients in bold are significant at $p<.05$

See Appendix A for variable definitions and descriptive statistics

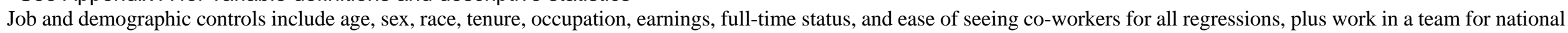

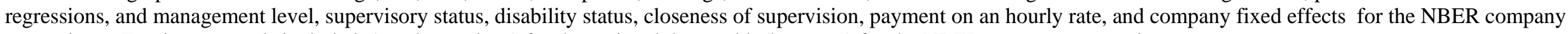
regressions. Earnings controls include ln(yearly earnings) for the national data and ln(base pay) for the NBER company regressions. 


\section{TABLE 2: Complementarities of Shared Capitalist Compensation in Affecting Employee Outcomes}

Each row represents results of a separate regression, with standard errors in parentheses underneath.

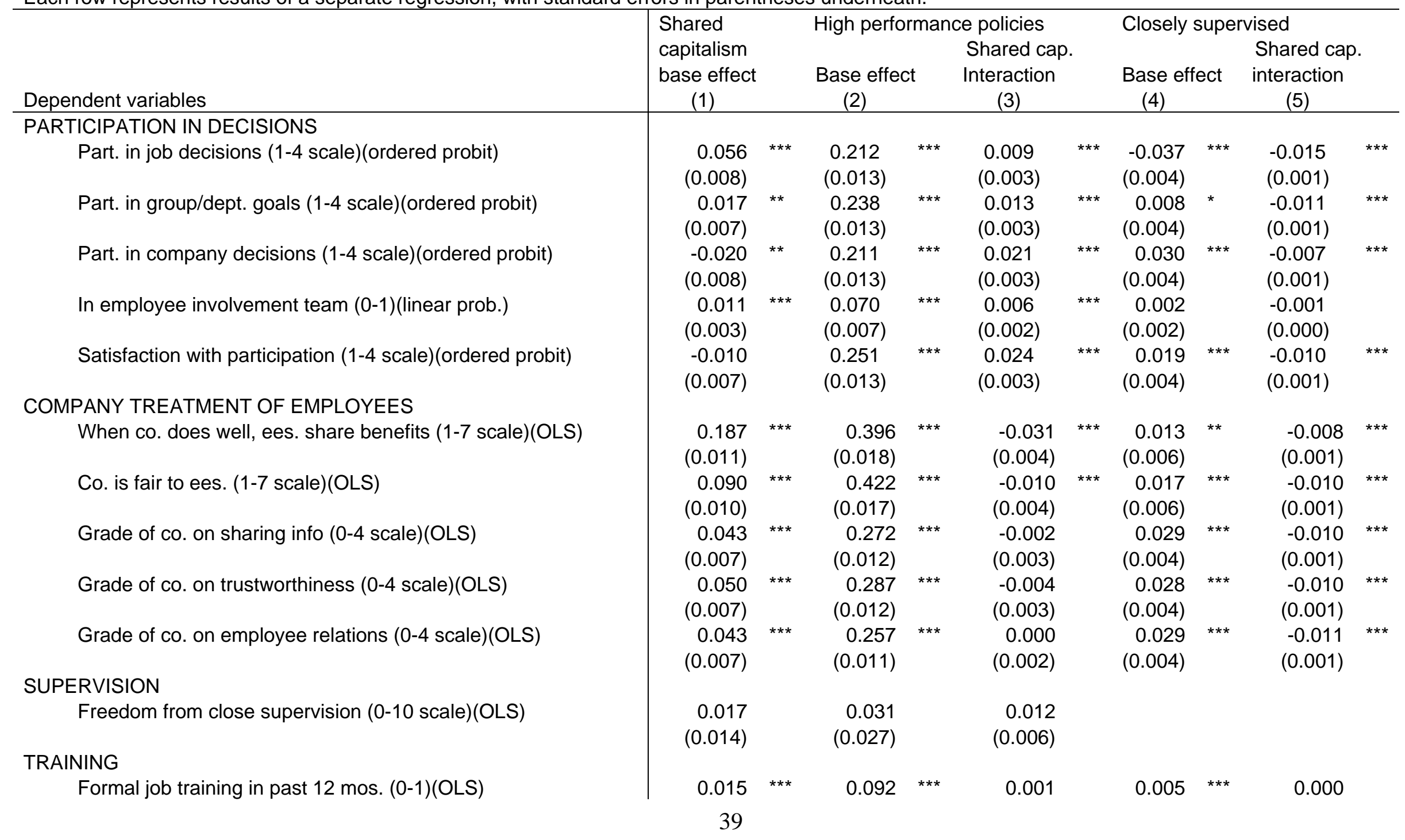


Hours of training in past 12 mos. (Tobit)

Informal job training from co-workers (1-4 scale)(ordered probit)

\section{PAY AND BENEFITS}

Fixed pay (natural logarithm)(OLS)

Fixed pay \% diff. from market (OLS)

Total compensation \% diff. from market (OLS)

Grade of co. on wages (0-4 scale)(OLS)

Grade of co. on benefits ( $0-4$ scale)(OLS)

\section{JOB SECURITY}

Not likely to lose job (1-4 scale)(ordered probit)

\section{JOB SATISFACTION}

Job satisfaction (1-7 scale)(OLS)

\begin{tabular}{|c|c|c|c|c|c|c|c|c|c|}
\hline (0.003) & & $(0.007)$ & & $(0.002)$ & & $(0.002)$ & & $(0.000)$ & \\
\hline 2.047 & $\star \star \star *$ & 11.048 & $\star \star \star *$ & 0.076 & & 0.344 & & -0.106 & * \\
\hline (0.398) & & (1.002) & & (0.209) & & (0.239) & & $(0.055)$ & \\
\hline 0.005 & & 0.188 & $\star \star *$ & 0.008 & $\star \star * *$ & 0.030 & $\star \star \star$ & -0.004 & $\star \star \star *$ \\
\hline (0.007) & & $(0.012)$ & & $(0.003)$ & & $(0.004)$ & & $(0.001)$ & \\
\hline 0.028 & $\star * *$ & 0.017 & $\star \star *$ & -0.001 & & -0.009 & $\star \star *$ & -0.001 & * \\
\hline (0.003) & & (0.005) & & (0.001) & & (0.002) & & $(0.000)$ & \\
\hline 0.249 & $\star *$ & 0.870 & $\star \star \star *$ & 0.012 & & 0.297 & $\star \star \star$ & -0.073 & $\star \star \star$ \\
\hline (0.124) & & (0.218) & & $(0.047)$ & & (0.071) & & $(0.016)$ & \\
\hline 0.558 & $\star * *$ & 0.771 & $\star * *$ & 0.094 & * & 0.184 & ** & -0.084 & $\star \star *$ \\
\hline$(0.134)$ & & (0.239) & & $(0.050)$ & & (0.078) & & (0.018) & \\
\hline 0.041 & $\star \star \star \star$ & 0.141 & $* * *$ & -0.002 & & 0.007 & ** & -0.006 & $\star * *$ \\
\hline (0.007) & & $(0.011)$ & & $(0.003)$ & & (0.004) & & $(0.001)$ & \\
\hline 0.057 & $\star \star \star *$ & 0.187 & $\star \star \star *$ & -0.008 & $\star \star \star *$ & 0.007 & * & -0.006 & $* * *$ \\
\hline (0.007) & & (0.011) & & $(0.002)$ & & (0.004) & & (0.001) & \\
\hline 0.065 & $\star * *$ & 0.098 & $\star \star \star *$ & 0.002 & & -0.029 & $\star \star *$ & -0.005 & $\star * *$ \\
\hline (0.006) & & $(0.015)$ & & $(0.003)$ & & (0.004) & & $(0.001)$ & \\
\hline-0.007 & & 0.264 & $* * *$ & 0.019 & $\star \star \star *$ & 0.001 & & -0.009 & $\star * *$ \\
\hline (0.008) & & $(0.014)$ & & $(0.003)$ & & (0.004) & & $(0.001)$ & \\
\hline
\end{tabular}

* $\mathrm{p}<.10$ ** $\mathrm{p}<.05$ *** $\mathrm{p}<.01$

See Appendix A for variable definitions and descriptive statistics

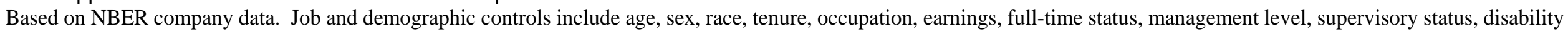
status, closeness of supervision, ease of seeing workers, payment on an hourly rate, and company fixed effects. 
Table A-1: Prevalence of Shared Capitalism Programs

\begin{tabular}{|c|c|c|c|c|}
\hline & & & Sample & zes \\
\hline & $\begin{array}{c}\text { Survey } \\
2002-2006\end{array}$ & dataset & GSS & NBER \\
\hline Bonus eligibility & & & & \\
\hline Profit sharing & $35.9 \%$ & $71.3 \%$ & 2386 & 41018 \\
\hline Gainsharing & $24.9 \%$ & $20.7 \%$ & 2386 & 41023 \\
\hline Size of most recent bonus, if eligible for any & & & & \\
\hline Mean dollar value & $\$ 6,265$ & $\$ 11,329$ & 693 & 26113 \\
\hline Median dollar value & $\$ 1,500$ & $\$ 2,000$ & 693 & 26113 \\
\hline Mean \% of pay & $8.9 \%$ & $12.1 \%$ & 645 & 22019 \\
\hline Median \% of pay & $4.6 \%$ & $5.7 \%$ & 645 & 22019 \\
\hline Employee ownership & & & & \\
\hline Own employer stock in any form & $19.4 \%$ & $64.0 \%$ & 2406 & 41206 \\
\hline Own employer stock through: & & & & \\
\hline Employee Stock Ownership Plan & & $8.1 \%$ & & 41109 \\
\hline Employee Stock Purchase Plan & & $17.6 \%$ & & 40990 \\
\hline 401(k) plan & & $33.5 \%$ & & 40885 \\
\hline Exercising options and keeping stock & & $5.0 \%$ & & 41032 \\
\hline Open market purchase & & $7.3 \%$ & & 41145 \\
\hline Value of employer stock, if own stock & & & & \\
\hline Dollar value: Mean & $\$ 63,130$ & $\$ 60,078$ & 318 & 25447 \\
\hline Median & $\$ 10,000$ & $\$ 14,375$ & 318 & 25447 \\
\hline$\%$ of pay: $\quad$ Mean & $81.7 \%$ & $65.0 \%$ & 302 & 22715 \\
\hline Median & $23.0 \%$ & $30.6 \%$ & 302 & 22715 \\
\hline$\%$ of wealth: Mean & & $19.6 \%$ & & 23141 \\
\hline Median & & $10.0 \%$ & & 23141 \\
\hline Stock options & & & & \\
\hline Currently hold stock options & $11.3 \%$ & $21.9 \%$ & 2392 & 41166 \\
\hline Ever granted stock options & & $22.3 \%$ & & 41166 \\
\hline Granted stock options last year & & $20.4 \%$ & & 41158 \\
\hline Value of stock options, if hold options: & & & & \\
\hline Mean dollar value of unvested options & & $\$ 112,882$ & & 8390 \\
\hline Mean dollar value of vested options & & $\$ 143,117$ & & 8497 \\
\hline Total dollar value: Mean & & $\$ 249,901$ & & 8656 \\
\hline Median & & $\$ 75,000$ & & 8656 \\
\hline$\%$ of pay: & & $183.7 \%$ & & 8403 \\
\hline Median & & $100.0 \%$ & & 8403 \\
\hline \% of wealth: & & $60.3 \%$ & & 8104 \\
\hline Median & & $28.6 \%$ & & 8104 \\
\hline Any of above programs & $44.9 \%$ & $85.7 \%$ & 2430 & 41206 \\
\hline
\end{tabular}

Source: Tabulated from GSS and NBER surveys. The GSS sample is limited to private for-profit employees. 
Table B-1: Participation in Decisions by Type of Shared Capitalism Plan

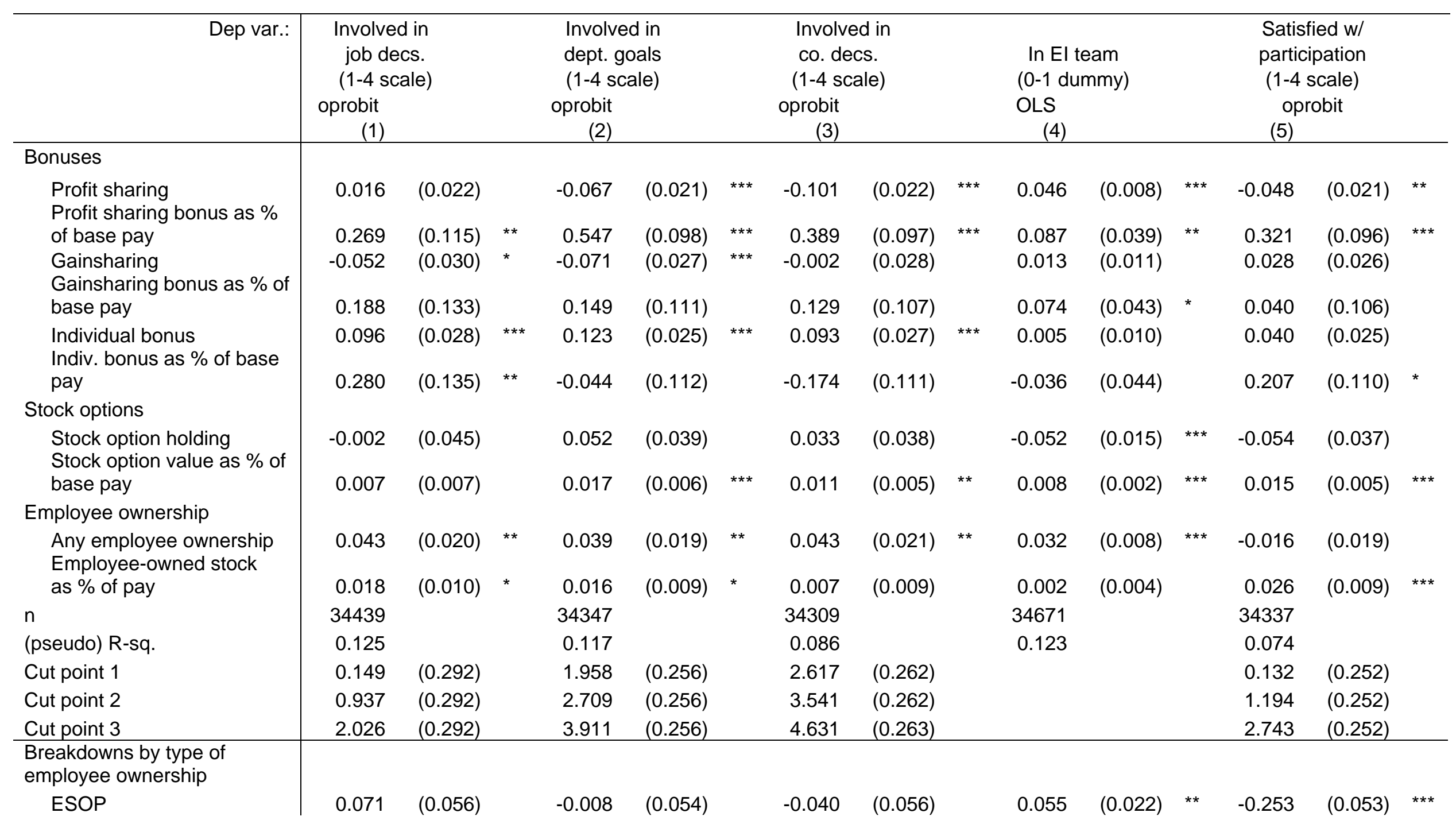




\begin{tabular}{|c|c|c|c|c|c|c|c|c|c|c|c|c|c|c|c|}
\hline ESOP stock as $\%$ of pay & 0.029 & $(0.022)$ & & 0.048 & $(0.021)$ & ** & 0.029 & $(0.020)$ & & 0.002 & $(0.008)$ & & 0.052 & $(0.020)$ & $\star \star \star *$ \\
\hline ESPP & 0.027 & $(0.044)$ & & 0.065 & (0.039) & * & 0.038 & $(0.040)$ & & -0.006 & $(0.016)$ & & 0.057 & $(0.038)$ & \\
\hline ESPP stock as \% of pay & -0.031 & $(0.036)$ & & -0.032 & $(0.031)$ & & -0.003 & $(0.030)$ & & 0.003 & $(0.012)$ & & -0.035 & $(0.030)$ & \\
\hline 401(k) stock & 0.031 & $(0.018)$ & & 0.016 & $(0.018)$ & & 0.032 & $(0.019)$ & * & 0.042 & $(0.007)$ & $\star \star \star *$ & 0.021 & $(0.018)$ & \\
\hline $401(k)$ stock as $\%$ of pay & 0.046 & $(0.017)$ & \multirow[t]{5}{*}{ *** } & 0.030 & $(0.015)$ & \multirow[t]{5}{*}{ ** } & 0.011 & $(0.016)$ & & -0.007 & $(0.006)$ & & 0.028 & $(0.015)$ & * \\
\hline Stock from options & -0.067 & $(0.043)$ & & 0.044 & $(0.038)$ & & 0.089 & $(0.037)$ & \multirow[t]{4}{*}{ ** } & 0.039 & $(0.015)$ & $* \star \star$ & -0.009 & $(0.037)$ & \\
\hline pay & 0.029 & $(0.025)$ & & -0.012 & $(0.021)$ & & -0.030 & $(0.020)$ & & -0.009 & $(0.008)$ & & 0.025 & $(0.020)$ & \\
\hline Open mkt. stock & -0.046 & $(0.032)$ & & 0.014 & $(0.028)$ & & 0.027 & $(0.029)$ & & 0.002 & $(0.011)$ & & 0.069 & $(0.028)$ & $\star \star \star \star ~$ \\
\hline pay & -0.072 & $(0.053)$ & & -0.046 & $(0.045)$ & & 0.000 & $(0.044)$ & & 0.061 & $(0.018)$ & *** & -0.044 & $(0.045)$ & \\
\hline \multicolumn{16}{|l|}{$\begin{array}{l}\text { ESOP coefficients without } \\
\text { fixed effects }\end{array}$} \\
\hline ESOP & 0.126 & $(0.035)$ & $\star \star \star *$ & 0.227 & $(0.033)$ & $* * \star$ & 0.252 & $(0.034)$ & $\star * *$ & 0.014 & $(0.013)$ & & -0.103 & $(0.032)$ & $* \star *$ \\
\hline ESOP stock as $\%$ of pay & 0.007 & $(0.021)$ & & 0.047 & $(0.019)$ & $\star \star \star *$ & 0.003 & $(0.018)$ & & -0.001 & $(0.007)$ & & 0.015 & $(0.018)$ & \\
\hline
\end{tabular}

${ }^{*} p<.10{ }^{* *} p<.05{ }^{\star * \star} p<.01$ (s.e. in parentheses)

$\wedge$ All regressions include the control variables from table 2. 
Table B-2: Company Treatment of Employees by Type of Shared Capitalism Plan

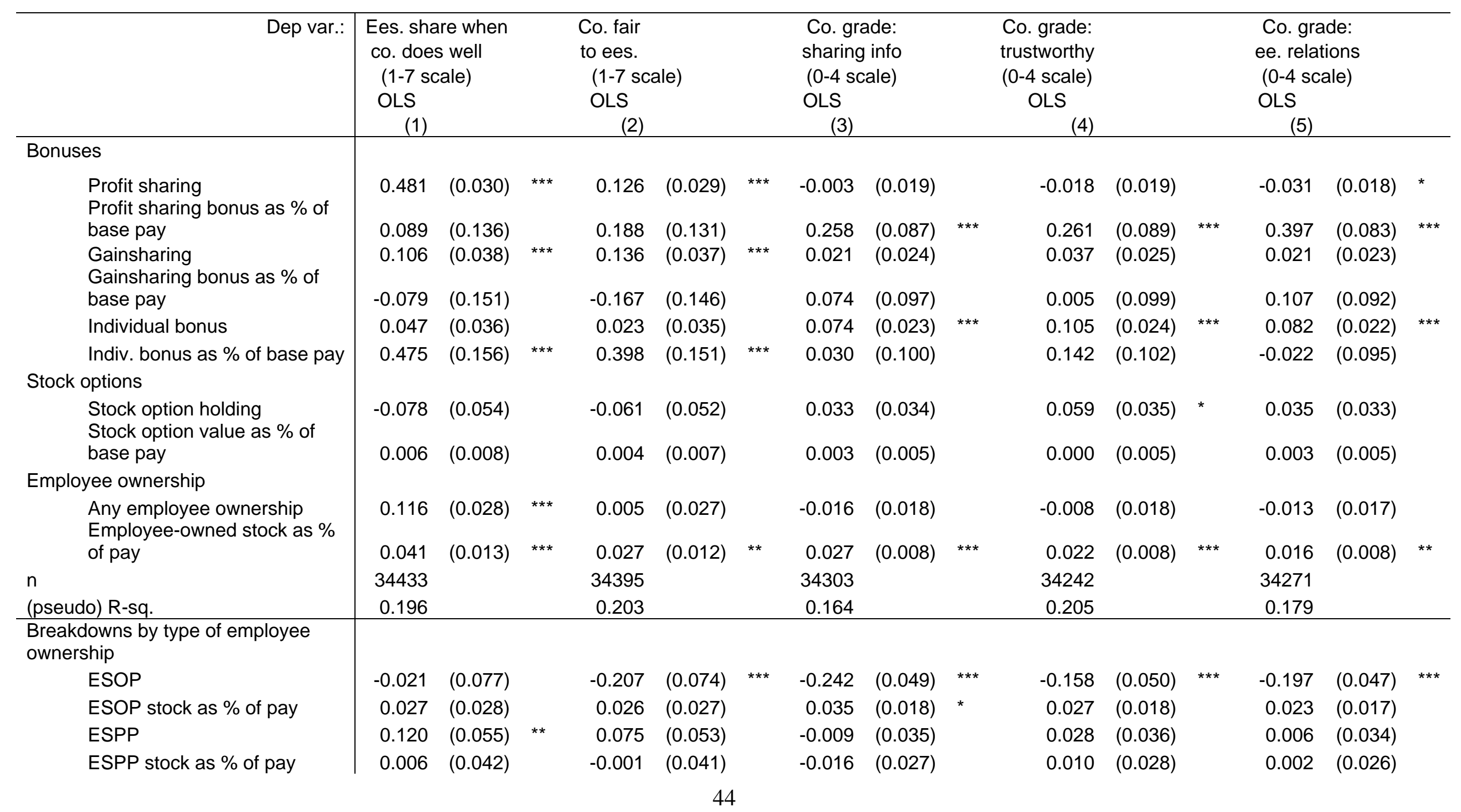




\begin{tabular}{|c|c|c|c|c|c|c|c|c|c|c|c|c|c|c|c|}
\hline 401(k) stock & 0.161 & $(0.025)$ & *** & 0.037 & $(0.025)$ & & 0.019 & $(0.016)$ & & 0.024 & $(0.017)$ & & 0.020 & $(0.016)$ & \\
\hline $401(k)$ stock as $\%$ of pay & 0.065 & $(0.022)$ & $* * *$ & 0.066 & $(0.021)$ & 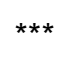 & 0.067 & $(0.014)$ & 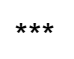 & 0.048 & $(0.014)$ & 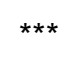 & 0.042 & $(0.013)$ & $\star \star \star *$ \\
\hline Stock from options & 0.042 & $(0.053)$ & & 0.001 & $(0.051)$ & & -0.088 & $(0.034)$ & 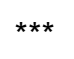 & -0.068 & $(0.034)$ & $\star *$ & -0.050 & $(0.032)$ & \\
\hline $\begin{array}{l}\text { Stock from options as \% of } \\
\text { pay }\end{array}$ & 0.008 & $(0.028)$ & & 0.031 & $(0.027)$ & & 0.024 & $(0.018)$ & & 0.027 & $(0.019)$ & & 0.016 & $(0.017)$ & \\
\hline Open mkt. stock & 0.010 & $(0.040)$ & & 0.055 & $(0.039)$ & & 0.056 & $(0.026)$ & ** & 0.062 & $(0.026)$ & ** & 0.030 & $(0.024)$ & \\
\hline Open mkt. stock as \% of pay & 0.013 & $(0.064)$ & & -0.010 & $(0.062)$ & & -0.029 & $(0.041)$ & & -0.071 & $(0.041)$ & * & -0.025 & $(0.039)$ & \\
\hline \multicolumn{16}{|l|}{$\begin{array}{l}\text { ESOP coefficients without fixed } \\
\text { effects }\end{array}$} \\
\hline ESOP & 0.231 & $(0.047)$ & $\star \star \star$ & -0.119 & $(0.045)$ & $\star \star \star *$ & -0.042 & $(0.030)$ & & -0.103 & $(0.030)$ & 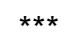 & -0.047 & $(0.028)$ & * \\
\hline ESOP stock as $\%$ of pay & 0.102 & $(0.026)$ & *** & 0.033 & $(0.025)$ & & 0.050 & $(0.017)$ & *** & 0.024 & $(0.017)$ & & 0.017 & $(0.016)$ & \\
\hline
\end{tabular}

${ }^{*} p<.10{ }^{* \star} p<.05{ }^{* \star \star} p<.01$ (s.e. in parentheses)

$\wedge$ All regressions include the control variables from table 2. 
Table B-3: Supervision and Training by Type of Shared Capitalism Plan

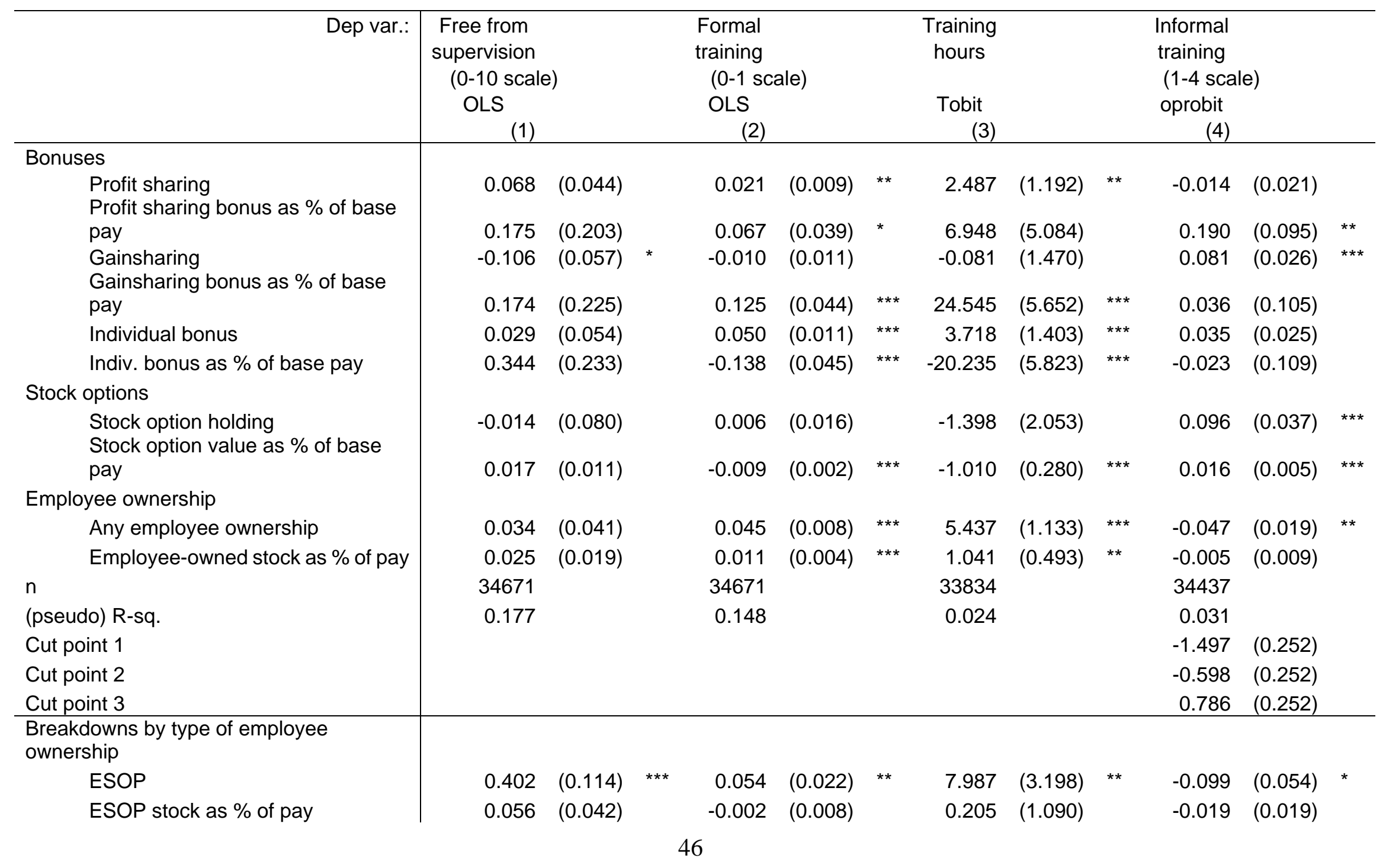




\begin{tabular}{|c|c|c|c|c|c|c|c|c|c|c|c|c|}
\hline ESPP & 0.051 & $(0.082)$ & & 0.011 & $(0.016)$ & & 2.352 & (2.120) & & 0.024 & $(0.038)$ & \\
\hline ESPP stock as \% of pay & -0.005 & (0.063) & & 0.015 & $(0.012)$ & & 0.986 & (1.595) & & -0.012 & $(0.030)$ & \\
\hline 401(k) stock & 0.057 & (0.038) & & 0.050 & $(0.007)$ & 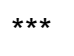 & 6.971 & $(1.056)$ & *** & -0.007 & $(0.018)$ & \\
\hline $401(k)$ stock as $\%$ of pay & 0.016 & $(0.032)$ & & 0.022 & $(0.006)$ & *** & 1.973 & $(0.835)$ & ** & 0.012 & $(0.015)$ & \\
\hline Stock from options as \% of pay & -0.018 & $(0.042)$ & & -0.007 & $(0.008)$ & & -0.086 & (1.068) & & -0.003 & $(0.020)$ & \\
\hline Open mkt. stock & -0.027 & $(0.060)$ & & -0.004 & $(0.012)$ & & 0.584 & (1.507) & & -0.028 & $(0.028)$ & \\
\hline Open mkt. stock as \% of pay & 0.046 & $(0.095)$ & & 0.003 & $(0.018)$ & & -0.268 & $(2.357)$ & & -0.012 & $(0.044)$ & \\
\hline ESOP & 0.403 & $(0.067)$ & *** & 0.169 & $(0.014)$ & *** & 15.145 & (1.857) & 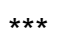 & -0.087 & $(0.032)$ & *** \\
\hline ESOP stock as $\%$ of pay & 0.121 & $(0.040)$ & $\star \star \star *$ & 0.018 & $(0.008)$ & *** & 2.043 & $(1.000)$ & ** & -0.012 & $(0.018)$ & \\
\hline
\end{tabular}

* $p<.10{ }^{* *} p<.05 * \star * p<.01$ (s.e. in parentheses)

$\wedge$ All regressions include the control variables from table 2 . 
Table B-4: Pay and Benefits by Type of Shared Capitalism Plan

\begin{tabular}{|c|c|c|c|c|c|c|c|c|c|c|c|c|c|c|c|}
\hline Dep var.: & \multicolumn{3}{|c|}{ Fixed pay } & \multicolumn{2}{|c|}{$\begin{array}{c}\text { Fixed pay } \\
\text { (\% diff. } \\
\text { from mkt.) }\end{array}$} & \multicolumn{4}{|c|}{$\begin{array}{l}\text { Total comp. } \\
\text { ( } \% \text { diff. } \\
\text { from mkt.) }\end{array}$} & \multicolumn{2}{|c|}{$\begin{array}{l}\text { Grade of co. on } \\
\text { Wages } \\
\text { (0-4 scale) }\end{array}$} & \multicolumn{4}{|c|}{$\begin{array}{l}\text { Benefits } \\
\text { (0-4 scale) }\end{array}$} \\
\hline Bonuses & & & & & & & & & & & & & & & \\
\hline $\begin{array}{l}\text { Profit sharing } \\
\text { Profit sharing bonus } \\
\text { as } \% \text { of base pay }\end{array}$ & $\begin{array}{l}0.015 \\
0.168\end{array}$ & $\begin{array}{l}(0.007) \\
(0.032)\end{array}$ & $\star \star *$ & $\begin{array}{l}0.222 \\
1.057\end{array}$ & $\begin{array}{l}(0.340) \\
(1.490)\end{array}$ & & $\begin{array}{r}-0.051 \\
8.130\end{array}$ & $\begin{array}{l}(0.362) \\
(1.587)\end{array}$ & $* * *$ & $\begin{array}{l}0.069 \\
0.194\end{array}$ & $\begin{array}{l}(0.018) \\
(0.085)\end{array}$ & 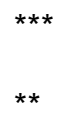 & $\begin{array}{l}0.068 \\
0.329\end{array}$ & $\begin{array}{l}(0.018) \\
(0.084)\end{array}$ & $* \star *$ \\
\hline $\begin{array}{l}\text { Gainsharing } \\
\text { Gainsharing bonus } \\
\text { as } \% \text { of base pay }\end{array}$ & $\begin{array}{r}0.028 \\
-0.079\end{array}$ & $\begin{array}{l}(0.009) \\
(0.035)\end{array}$ & $\star * \star *$ & $\begin{array}{l}0.374 \\
-0.664\end{array}$ & $\begin{array}{l}(0.439) \\
(1.668)\end{array}$ & & $\begin{array}{r}1.544 \\
-3.522\end{array}$ & $\begin{array}{l}(0.456) \\
(1.765)\end{array}$ & $\star \star *$ & 0.059 & $\begin{array}{l}(0.024) \\
(0.095)\end{array}$ & & 0.021 & $\begin{array}{l}(0.024) \\
(0.094)\end{array}$ & \\
\hline $\begin{array}{l}\text { Individual bonus } \\
\text { Indiv. bonus as \% of } \\
\text { base pay }\end{array}$ & $\begin{array}{l}0.007 \\
0.039\end{array}$ & $\begin{array}{l}(0.008) \\
(0.036)\end{array}$ & & $\begin{array}{r}-0.725 \\
4.148\end{array}$ & $\begin{array}{l}(0.423) \\
(1.712)\end{array}$ & * & $\begin{array}{l}-0.607 \\
12.875\end{array}$ & $\begin{array}{l}(0.444) \\
(1.832)\end{array}$ & $* * *$ & $\begin{array}{l}0.023 \\
0.193\end{array}$ & $\begin{array}{l}(0.023) \\
(0.098)\end{array}$ & ** & $\begin{array}{r}0.089 \\
-0.119\end{array}$ & $\begin{array}{l}(0.022) \\
(0.097)\end{array}$ & $* * *$ \\
\hline Stock options & & & & & & & & & & & & & & & \\
\hline $\begin{array}{l}\text { Stock option holding } \\
\text { Stock option value } \\
\text { as } \% \text { of base pay }\end{array}$ & $\begin{array}{l}0.160 \\
0.012\end{array}$ & $\begin{array}{l}(0.013) \\
(0.002)\end{array}$ & $\star \star * \star$ & $\begin{array}{l}0.594 \\
0.282\end{array}$ & $\begin{array}{l}(0.629) \\
(0.081)\end{array}$ & $\star * *$ & $\begin{array}{l}1.013 \\
0.601\end{array}$ & $\begin{array}{l}(0.666) \\
(0.088)\end{array}$ & $\star * *$ & $\begin{array}{r}-0.002 \\
0.007\end{array}$ & $\begin{array}{l}(0.033) \\
(0.005)\end{array}$ & & $\begin{array}{l}0.024 \\
0.002\end{array}$ & $\begin{array}{l}(0.033) \\
(0.005)\end{array}$ & \\
\hline $\begin{array}{l}\text { Employee ownership } \\
\text { Any employee } \\
\text { ownership } \\
\text { Employee-owned } \\
\text { stock as \% of pay }\end{array}$ & $\begin{array}{l}0.066 \\
-0.009\end{array}$ & $\begin{array}{l}(0.007) \\
(0.003)\end{array}$ & 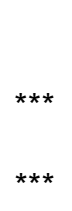 & $\begin{array}{l}0.012 \\
-0.127\end{array}$ & $\begin{array}{l}(0.308) \\
(0.158)\end{array}$ & & $\begin{array}{l}0.251 \\
0.244\end{array}$ & $\begin{array}{l}(0.331) \\
(0.158)\end{array}$ & & $\begin{array}{r}-0.008 \\
0.000\end{array}$ & $\begin{array}{l}(0.016) \\
(0.008)\end{array}$ & & $\begin{array}{l}0.040 \\
0.002\end{array}$ & $\begin{array}{l}(0.016) \\
(0.008)\end{array}$ & $\star *$ \\
\hline $\mathrm{n}$ & 27359 & & & 27320 & & & 26401 & & & 34408 & & & 34363 & & \\
\hline (pseudo) R-sq. & 0.765 & & & 0.063 & & & 0.137 & & & 0.108 & & & 0.164 & & \\
\hline
\end{tabular}




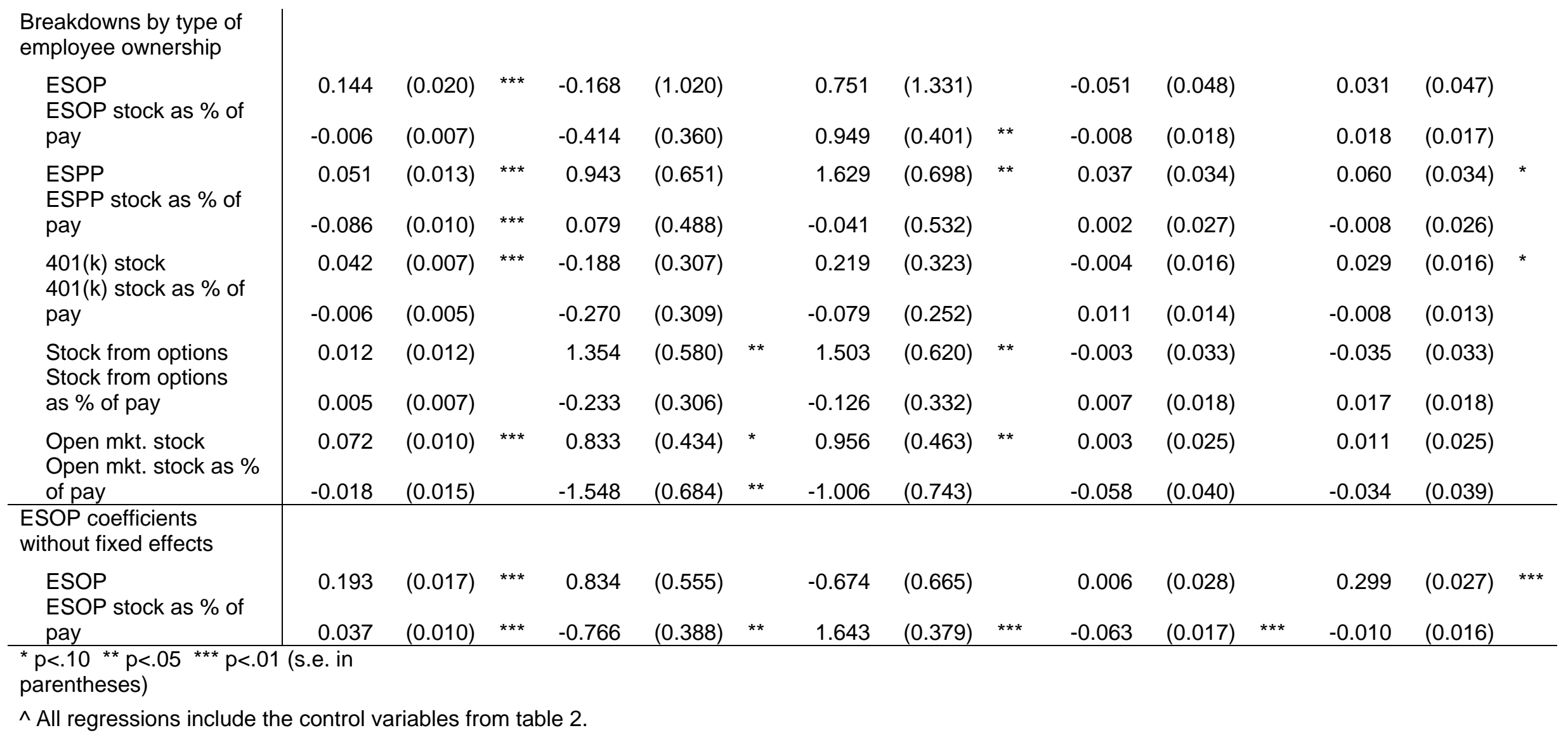


Table B-5: Job Security and Satisfaction by Type of Shared Capitalism Plan

\begin{tabular}{|c|c|c|c|c|c|c|}
\hline Dep var.: & $\begin{array}{l}\text { Not likely to } \\
\text { lose job } \\
\text { (1-4 scale) } \\
\text { oprobit } \\
(1)\end{array}$ & & & $\begin{array}{l}\text { Job } \\
\text { sfaction } \\
\text { scale) } \\
\text { OLS } \\
\quad(2)\end{array}$ & & \\
\hline \multicolumn{7}{|l|}{ Bonuses } \\
\hline Profit sharing & 0.102 & $(0.021)$ & $* \star *$ & -0.063 & $(0.023)$ & *** \\
\hline Profit sharing bonus as $\%$ of base pay & 0.486 & $(0.098)$ & *** & 0.255 & $(0.105)$ & ** \\
\hline Gainsharing & 0.068 & $(0.027)$ & *** & 0.025 & $(0.029)$ & \\
\hline Gainsharing bonus as \% of base pay & -0.021 & $(0.109)$ & & 0.270 & $(0.117)$ & ** \\
\hline Individual bonus & 0.057 & $(0.026)$ & ** & 0.023 & $(0.028)$ & \\
\hline Indiv. bonus as \% of base pay & -0.046 & $(0.112)$ & & 0.168 & $(0.121)$ & \\
\hline \multicolumn{7}{|l|}{ Stock options } \\
\hline Stock option holding & 0.040 & $(0.039)$ & & -0.008 & $(0.041)$ & \\
\hline Stock option value as \% of base pay & 0.011 & $(0.005)$ & ** & 0.007 & $(0.006)$ & \\
\hline \multicolumn{7}{|l|}{ Employee ownership } \\
\hline Any employee ownership & 0.082 & $(0.020)$ & $\star \star \star *$ & -0.006 & $(0.021)$ & \\
\hline Employee-owned stock as \% of pay & 0.018 & $(0.009)$ & ** & 0.001 & $(0.010)$ & \\
\hline $\mathrm{n}$ & 34671 & & & 34525 & & \\
\hline (pseudo) R-sq. & 0.042 & & & 0.107 & & \\
\hline Cut point 1 & -1.917 & $(0.259)$ & & & & \\
\hline Cut point 2 & -1.175 & $(0.259)$ & & & & \\
\hline Cut point 3 & 0.476 & $(0.259)$ & & & & \\
\hline \multicolumn{7}{|l|}{ Breakdowns by type of employee ownership } \\
\hline ESOP & -0.001 & $(0.056)$ & & -0.038 & $(0.059)$ & \\
\hline ESOP stock as \% of pay & 0.042 & $(0.021)$ & ** & -0.002 & $(0.022)$ & \\
\hline ESPP & -0.058 & $(0.040)$ & & -0.027 & $(0.042)$ & \\
\hline ESPP stock as \% of pay & -0.005 & $(0.031)$ & & -0.001 & $(0.033)$ & \\
\hline
\end{tabular}




\begin{tabular}{|c|c|c|c|c|c|c|}
\hline 401(k) stock & 0.096 & $(0.018)$ & *** & -0.001 & $(0.020)$ & \\
\hline $401(k)$ stock as $\%$ of pay & 0.054 & (0.015) & *** & 0.018 & $(0.017)$ & \\
\hline Stock from options & -0.089 & (0.038) & ** & -0.006 & $(0.041)$ & \\
\hline Stock from options as \% of pay & 0.013 & $(0.020)$ & & -0.003 & $(0.022)$ & \\
\hline Open mkt. stock as \% of pay & 0.038 & $(0.046)$ & & -0.033 & $(0.049)$ & \\
\hline Open mkt. stock & 0.008 & $(0.029)$ & & 0.005 & $(0.031)$ & \\
\hline $\begin{array}{l}\text { ESOP coefficients without fixed effects } \\
\text { ESOP }\end{array}$ & 0.299 & $(0.034)$ & *** & 0.090 & $(0.036)$ & $\star \star \star \star ~$ \\
\hline ESOP stock as $\%$ of pay & 0.043 & $(0.020)$ & ** & -0.029 & $(0.020)$ & \\
\hline
\end{tabular}

${ }^{*} p<.10{ }^{* *} p<.05{ }^{* * *} p<.01$ (s.e. in parentheses)

$\wedge$ All regressions include the control variables from Table 2. 
Figure 1: The Contingent Effects of Shared Capitalism on Job Satisfaction

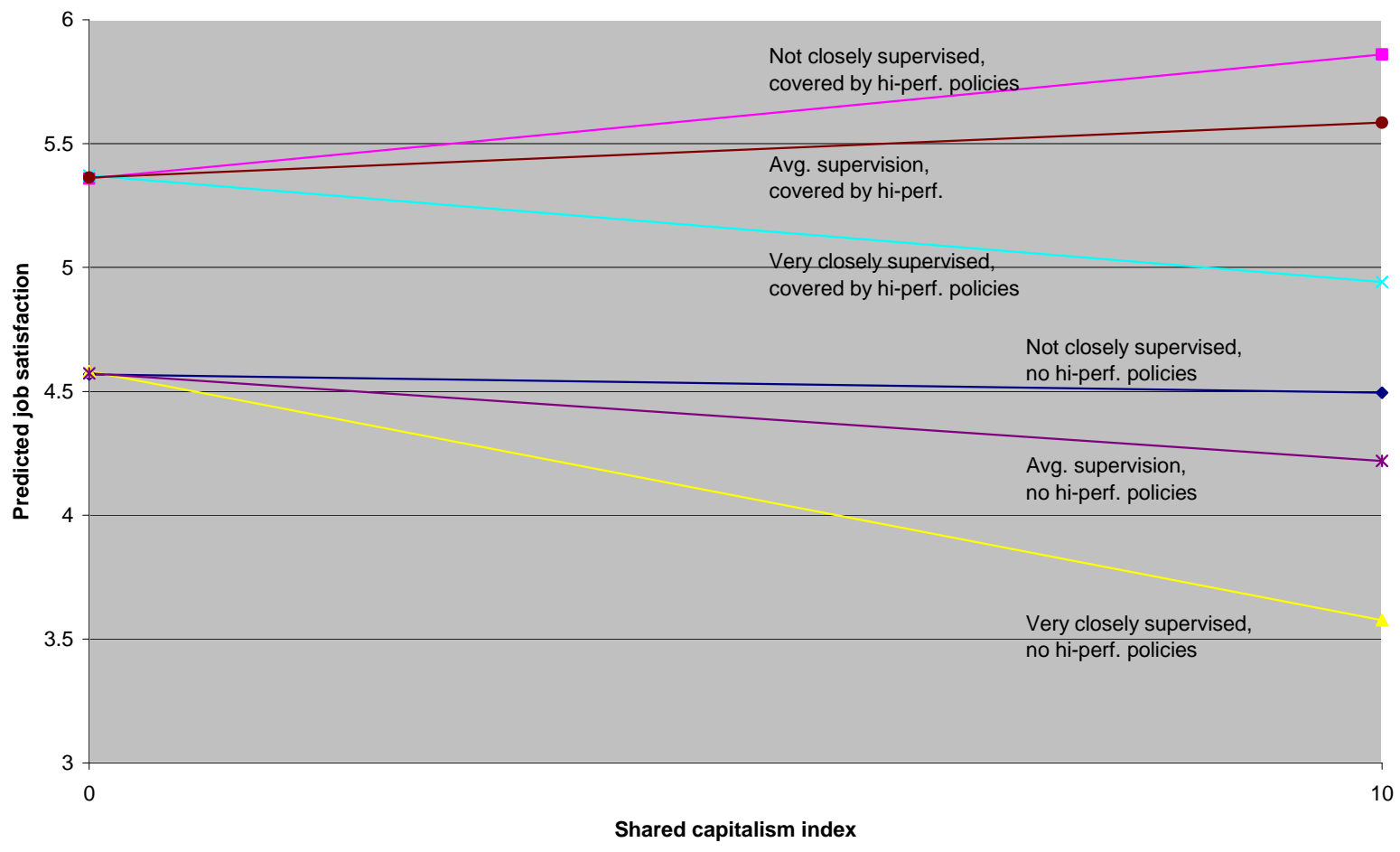


Figure B1: Distribution of Shared Capitalism Index in GSS

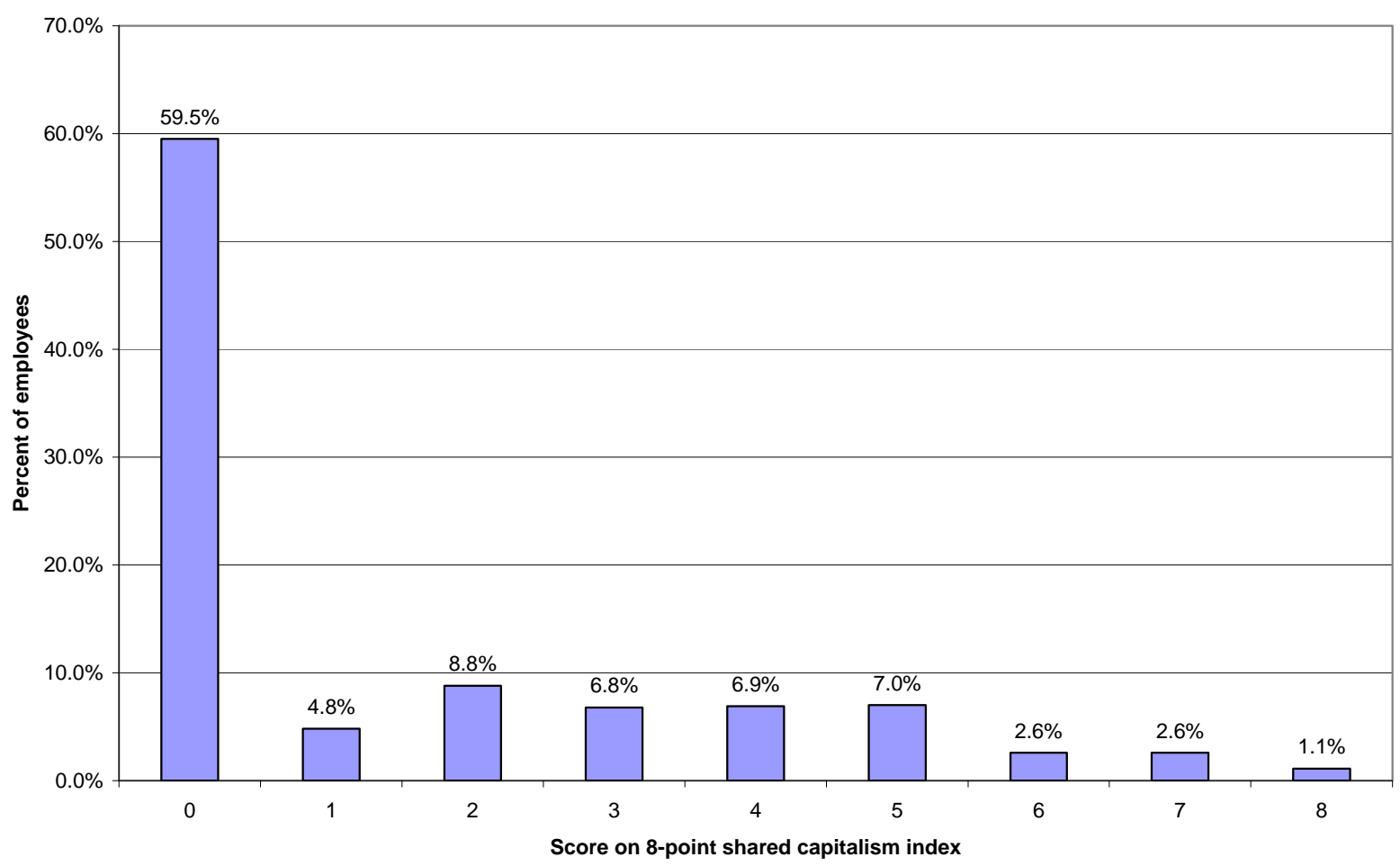


Figure B2: Distribution of Shared Capitalism Index in NBER Companies

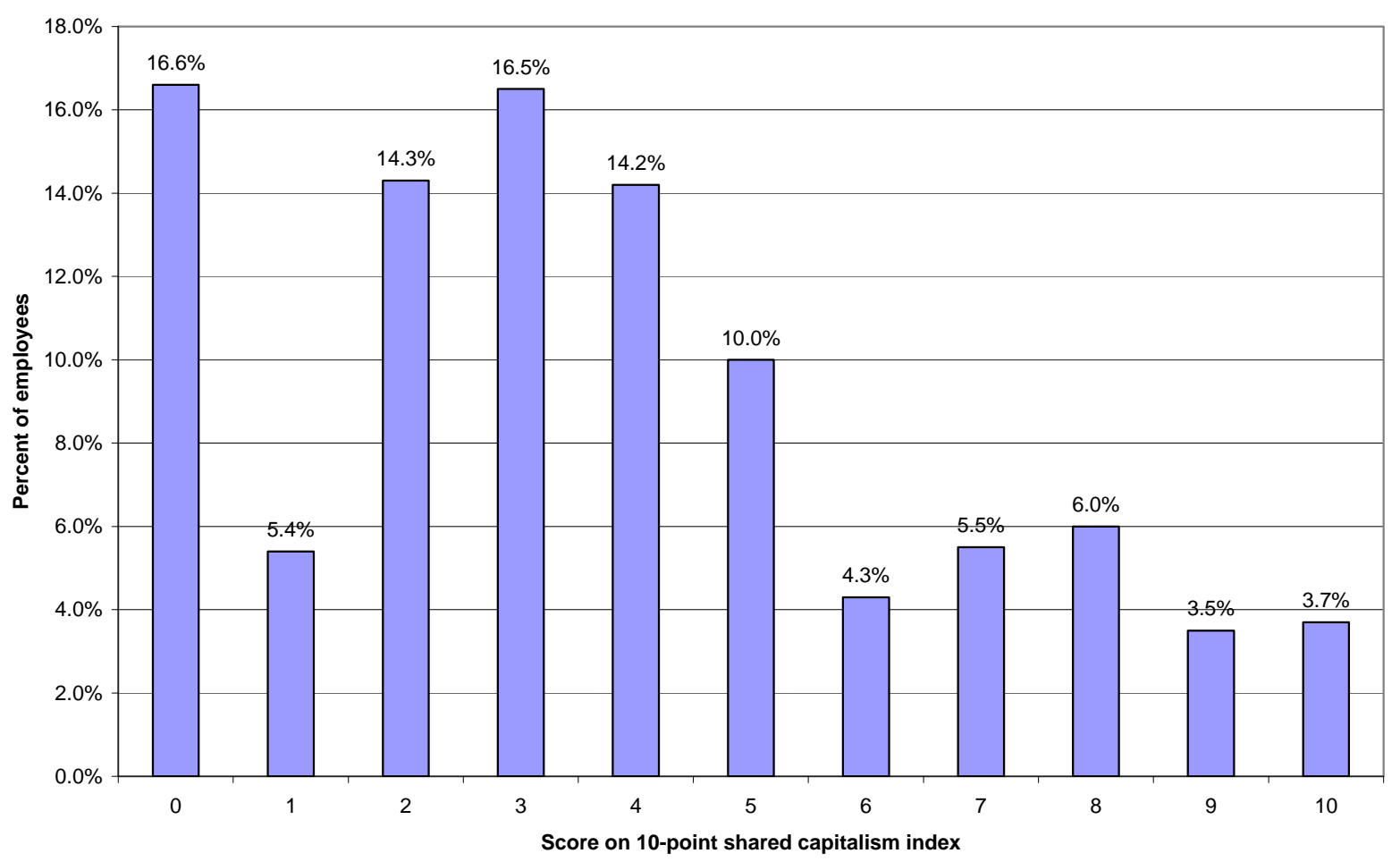

